Article

\title{
Application of Suitability Modeling in Establishing a New Bicycle-Pedestrian Path: The Case of the Abandoned Kanfanar-Rovinj Railway in Istria
}

\author{
Ariana Modesto ${ }^{1}$, Monika Kamenečki ${ }^{2}$ and Dora Tomić Reljić ${ }^{2, *(D)}$ \\ 1 Independent Researcher, 52352 Kanfanar, Croatia; ariana.modesto95@gmail.com \\ 2 Faculty of Agriculture, School of Landscape Architecture, University of Zagreb, 10000 Zagreb, Croatia; \\ mkamenecki@agr.hr \\ * Correspondence: dtomic@agr.hr
}

Citation: Modesto, A.; Kamenečki, M.; Tomić Reljić, D. Application of Suitability Modeling in Establishing a New Bicycle-Pedestrian Path: The Case of the Abandoned Kanfanar-Rovinj Railway in Istria. Land 2021, 10, 600. https://doi.org/ 10.3390/land 10060600

Academic Editor:

Cristina Herrero-Jáuregui

Received: 30 April 2021

Accepted: 3 June 2021

Published: 4 June 2021

Publisher's Note: MDPI stays neutral with regard to jurisdictional claims in published maps and institutional affiliations.

Copyright: (C) 2021 by the authors Licensee MDPI, Basel, Switzerland. This article is an open access article distributed under the terms and conditions of the Creative Commons Attribution (CC BY) license (https:// creativecommons.org/licenses/by/ $4.0 /)$.

\begin{abstract}
This paper presents research on the conversion of the abandoned Kanfanar-Rovinj railway into a bicycle-pedestrian path, with the aim of including it in the existing network of bicyclepedestrian paths in the Istria County in Croatia. This would enable better connection of the repurposed railway corridor with the surrounding natural and cultural values and better use of the spatial potential, which would create more favorable conditions for the revitalization of the wider rural environment. In order to identify the existing potential of the area, as well as the impact of the proposed intervention on critical areas, a method of multicriteria analysis was used. The result of the analysis was a model of the suitability of the space, i.e., five value categories that make the space more or less suitable for accommodating new pedestrian and bicycle paths. In order to emphasize the importance of individual spatial contents in the modeling process, the method of weighted linear combination was used. Finally, the nature of the project and its potential impact on the environment have conditioned the selection of the appropriate aspect of the model and of the space's suitability, which is further used for locating the new pedestrian and bicycle paths.
\end{abstract}

Keywords: Kanfanar-Rovinj railway; spatial potential; suitability of space; multicriteria analysis; bicycle-pedestrian path; greenway

\section{Introduction}

The $21 \mathrm{~km}$ long Kanfanar-Rovinj railway was opened to traffic on 20 September 1876 due to the need to connect factories and strengthen industry in the city of Rovinj.

Like many railway networks in the world that were closed in the 1960s [1,2], the cessation of traffic on the Kanfanar-Rovinj railway occurred in that period (1966), which can be justified for several reasons.

Strengthening the competitiveness of road traffic in Istria in the 1960s and increasing the number of private vehicles [3], a lack of money for railway reconstruction, and a reduced transport volume [4] were the main arguments for the decision to abolish the railway. After the railway traffic ceased, the infrastructure slowly became subject to degradation and oblivion, which, however, did not happen with the memory of the local population.

The railway, in the minds of Istrians and Rovinj residents, was not just another mode of transport, but truly symbolized, from the very beginning, progress, success, economic power, and connection with the "world" [4]. Given the different and complex needs of potential users and the economic structure of the peninsula where tourism is the predominant activity [5], the idea of reorganizing the route of the former railway into a bicycle-pedestrian path follows modern-world trends by proposing to turn neglected railway infrastructure into green paths, or so-called "greenways" [6]. It can be stated that the greenway idea started in the United States with the Trails Act in 1968 and has continued until today with a non-profit organization (the Rails-To-Trails Conservancy). The greenway 
network was built from old railway lines and converted to create environmental, economic, and social benefits for people $[7,8]$. This transformation attests to many European and international examples of the conversion of these neglected structures into bicycle paths intended for sustainable mobility. "Greenways" or "green corridors" were often used as a framework for establishing open public spaces in urban or rural areas. Further scientific research has confirmed that "green corridors" have a strategic function as recreational trails (without motorized vehicles) that enrich the perspective of urban mobility in the local context $[9,10]$. From the spatial point of view, an abandoned railway corridor can be defined as a 'marginal space' that, together with its surrounding space, creates a striking impression through a number of elements and meanings that unite and enable a deeper understanding of it in the context of stratification and complexity [11]. Istria County is recognized as a tourist destination throughout the year and needs to develop sustainable mobility that will bring about additional economic and social benefits but at the same time conserving and repairing environmental, cultural, and historic value. The aim is for this bicycle-pedestrian path to be used as a conceptual plan to provide a connection with the peninsula's historical, cultural, and natural heritage and create all types of ecotourism that promotes the participation of the local population. A case study from Portugal [12] suggests that a network of green corridors also needs to use existing infrastructure in order to minimize the environmental and cultural landscape impact and increase the accessibility to all users. This connectivity principle can be applied using a comprehensive analysis of the landscape, a detailed management and maintenance plan, and a holistic design that includes community participation [12]. Ferretti and Degioanni (2017) [13] emphasize that out-of-use railways represent potential routes that can provide new activities while supporting sustainable local development. This is confirmed by other authors $[2,14]$ stating that such spaces are essentially heritage because, by turning them into green corridors, they can be used to provide new features to local communities in line with sustainable development principles. Moreover, Noh (2019) in his research found a positive impact of the transformation of an abandoned railway line into a green corridor on the price of housing located in the immediate vicinity [15]. Revitalization of such an area has a number of positive effects in improving the natural and cultural qualities of the landscape, especially its social aspect, which raises the quality of life and enables economic development [16].

As a positive aspect of space transformation, Ferretti and Degioanni (2019) point out the relatively small reclamation costs compared with some other types of conversion, such as areas that were used for heavy industry [13]. Thanks to the many recognized positive attributes, the narrower area of the railway deserves to be visited and discovered. This is achievable by informing visitors about the railway and directing them to it.

Analyzing the wider context, it was noticed that the railway route is surrounded by valuable natural areas-protected parts of nature and Natura 2000 Ecological Network sites-some of which run parallel to the corridor, while others are located in its peripheral area.

Considering that such valuable natural areas attract a significant number of visitors, it was necessary to examine their relationship and whether there is currently a circulation of pedestrians and cyclists from one area to another and vice versa. Within the Spatial Program of the Lim Bay and Lim Valley [17], local roads and a network of forest and macadam roads that connect Lim Bay and Lim Valley together with the wider spatial context are mentioned. Since the railway corridor lies parallel to their southern part, it can also be interpreted as part of the wider spatial context.

Most of the macadam roads are poorly connected to the surrounding spatial attractions and insufficiently equipped with facilities for cyclists and other visitors. In order to make the best use of their strategic position between the railway corridor, protected natural areas, and the ecological network of Natura 2000, it is necessary to increase the attractiveness of such trails and thus enable a greater circulation of people from the railway to protected areas and vice versa. 
Increasing the attractiveness means connecting the trail with the surrounding spatial potentials (natural, cultural, and aesthetic-perceptual) and the organization of adequate content.

Given the complexity of the landscape in which the existing roads would build on the surrounding potentials_-and thus create a network of new hiking and biking trails_-an unavoidable factor is the assessment of the extent to which the project may affect the landscape. In doing so, the aim is to harness the potentials of space, but simultaneously to reduce the impact on vulnerable areas in order to preserve their characteristics. To achieve such a balance between both opposing aspects of space-development and protection-the method of suitability modeling [18-20] was used as an example of the wider railway spatial context. A spatial suitability model, with an emphasis on cartographic modeling, should be used for the identification of suitable areas for a specific use and to determine the propriety of an area for a particular use $[18,19,21]$. As far back as 40 years ago, Hopkins (1977) in his paper dealing with the analysis of methods for generating space suitability maps expressed that such analyses are a standard part of planning analyses at many scales. Land use suitability maps arise from GIS-based multicriteria analysis. In order to determine the appropriateness of a certain area for a particular land use, suitability modeling has to incorporate many factors (physical, natural, cultural, etc.). So, when there are multiple criteria and conflicting priorities, it is necessary to use multicriteria analysis [22,23]. When used in decision-making, Phua and Minowa (2005) divide multicriteria analysis into two classes; multi-attribute and multi-objective decision-making [24]. The first evaluates a finite feasible set of alternatives and selects the best one according to attributes, while the second focuses on a series of conflicting objectives when choosing the best. Since GIS-based suitability modeling is based on map overlaying, it is important to choose an appropriate logic model. The first model is Boolean logic [19,21-23], classical true/false logic, which is utilized for the identification of areas that are not suitable for consideration [22]. The deficiency of this approach is the lack of the analytical possibility of examining which of the areas fulfilling the criteria is the most appropriate [21]. Therefore, the method of multicriteria analysis called weighted linear combination (WLC) is more appropriate in land use suitability modeling. It is based on fuzzy logic $[19,22,23,25]$, where each factor is multiplied by a weight, so one factor can prevail over another [22,23]. Other approaches mentioned in the literature are ordered weighted average [23], where weight factors are aggregated to enable an evaluation of the decisions in terms of trade-offs and risks, and the Index Overlaying Model [19], which is used to determine an effective factor's weight according to its relative importance.

Because of the development needs of the bicycle pedestrian path, an analysis showed that some spatial factors are expected to have a greater significance compared with some others: customized services for pedestrians and cyclists (e.g., accommodation units) and the vicinity of panoramic points. In order to highlight such contents in relation to others, the WLC method [22] was implemented, which can also be considered a hybrid of qualitative and quantitative methods [26,27]. Given the large number of factors and the diversity of data sources when reconciling different criteria in the decision-making process, Feizizadeh and Keinberger (2017) [28] emphasize the importance of uncertainty in the final results. Jiang and Eastman $[25,29]$ see as a problem with the WLC method that standardized factors represent a possible advantage (i.e., vulnerability or attractiveness, depending on the level of analysis, author's remark); in doing so, a higher value represents a greater suitability of the site for a particular use.

The aim of this study is to improve GIS-based spatial analysis by using landscape suitability modeling, as it allows for the inclusion of different types of spatial data important to a specific activity. The approach presented can be utilized for the allocation of other developmental activities as well, which may contribute to the holistic sustainable ecotourism of the Istria region. 


\section{Materials and Methods}

\subsection{Case Study}

Since the railway corridor starts in the settlement of Kanfanar and ends in the area of the city of Rovinj (Figure 1), it is necessary to consider the territory of these administrative units as a narrower area of influence of the railway. The wider area of influence extends beyond the boundaries of the mentioned areas to other neighboring municipalities, whose territory also includes protected natural areas. At the national level, such areas are categorized as Protected Areas of Nature, while in the European context they are included in the network of Natura 2000 protected sites.

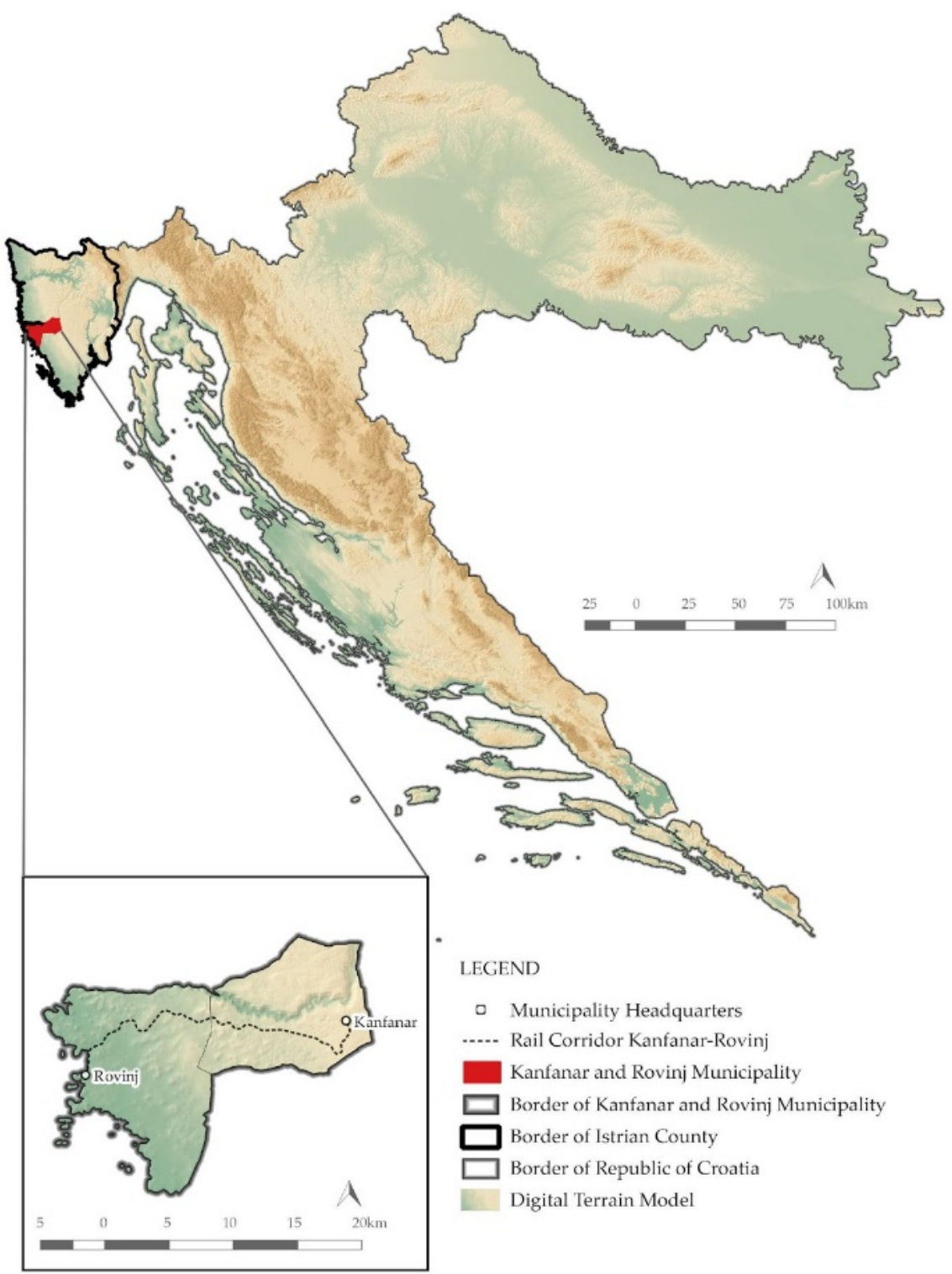

Figure 1. Location of the railway in the regional and national context.

Of the protected natural areas, the most prominent are the Significant Landscape and Special Reserve in the Sea Lim Bay and the planned protected area of Lim Valley. These areas lie along the entire corridor of the railway and are 1 to $4 \mathrm{~km}$ of air distance away. The bay itself is a typical example of a submerged canyon valley in karst and is characterized as a first-class natural phenomenon of great scientific and aesthetic value. It is about 10 $\mathrm{km}$ long and $33 \mathrm{~m}$ deep, with an average width of $600 \mathrm{~m}$ and a canyon side height of up to $150 \mathrm{~m}$. Due to microclimatic conditions, the terrestrial part is a habitat of macchia and 
the sub-Mediterranean community of Quercus pubescens and Quercus cerris oaks, while the marine part, due to the special properties of the marine environment, provides living conditions for an abundance of marine fauna and flora [30].

Areas that are protected at the national level also form an integral part of the Natura 2000 network, i.e., areas in Europe that are important for the conservation of species and habitat types. This category includes the land and sea part of the Lim Bay, the seawaters of western Istria, and the wider Rovinj area (Figure 2).
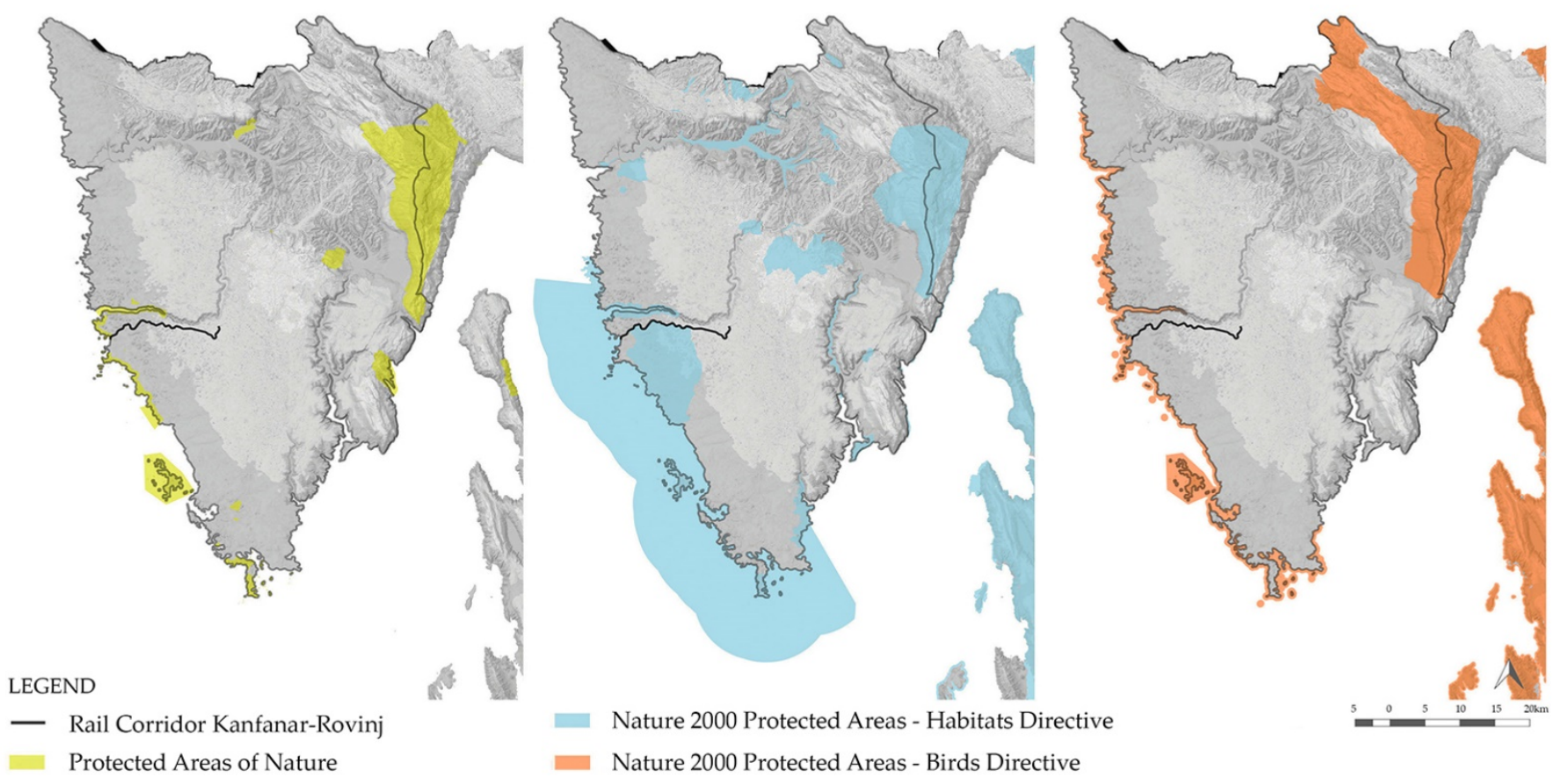

Figure 2. Protected areas of nature with Natura 2000 sites in Istria County.

While the seawaters of western Istria are important area for the conservation of both birds and species with a habitat type, in the Greater Rovinj area there are communities of eumediterranean Thero-Brachypodietea grasslands and coastal lagoons that are on the list of endangered and rare habitat types of national and European importance [31].

\subsection{Data Compilation}

In order to collect data for the multicriteria analysis, an analysis of spatial plans at the regional and local level [32-40] and an analysis of the relevant Spatial Program basis [17] were performed. For spatial data that were not recorded in the spatial planning documentation, the Bioportal Nature Protection Information System [30] and ENVI The Environmental Atlas (v1.7.5.) [41] databases were consulted. During the modeling of inventory maps, the official database of the Department of Ornamental Plants, Landscape Architecture and Garden Art was consulted too. The step that precedes the multicriteria analysis is the inventory of spatial contents that are crucial for cycling and hiking [42,43]. These data are intended primarily for cyclists and pedestrians and are available in GPX Exchange Format; however, they were converted to shapefile format for performing the multicriteria analysis (Table 1).

Analysis of the Spatial Plan of the Istria County [32] and the Spatial Program basis of the Lim Bay and Lim Valley [17] identified relevant factors influencing the attractiveness of the area: ponds, underground facilities open to visit, protected natural areas and sites of the Natura 2000 Ecological Network, cultural factors, and lookouts. Due to their location along the Lim Bay and distinct aesthetic and perceptual potential, the lookouts were recognized as an important factor in increasing the attractiveness of the pedestrian trail. It was assessed as an area of distinct aesthetic and perceptual potential. 
Table 1. Database.

\begin{tabular}{|c|c|c|c|c|}
\hline Type of Data & Name of Data & Source & Downloaded & Mapped by Authors \\
\hline TIFF & Digital Elevation Model & & yes & no \\
\hline \multirow{2}{*}{$\begin{array}{l}\text { GPX, SHP, } \\
\text { GRD }\end{array}$} & Bicycle trails & {$[42]$} & yes & no \\
\hline & Pedestrian trails & [43] & yes & no \\
\hline \multirow{2}{*}{ SHP, GRD } & Accomodation units & [42] & no & yes \\
\hline & Manifestations & Istria Tourist Board & no & yes \\
\hline \multirow{4}{*}{ SHP, GRD } & Ponds & $\begin{array}{c}\text { Invasive Species Centre } \\
\text { Institute for Agriculture and } \\
\text { Tourism, Poreč }\end{array}$ & yes & no \\
\hline & Land cover & [41] & yes & no \\
\hline & $\begin{array}{l}\text { Underground objects open to } \\
\text { visitors (pits and caves) }\end{array}$ & [30] & yes & no \\
\hline & $\begin{array}{l}\text { Protected Areas of Nature, Natura } \\
2000 \text { sites }\end{array}$ & {$[30]$} & yes & no \\
\hline SHP, GRD & Sources of water & {$[33-35,37-40]$} & no & yes \\
\hline SHP, GRD & Cultural heritage & {$[33-35,37-40]$} & no & yes \\
\hline SHP, GRD & Lookouts & [17] & no & yes \\
\hline SHP, GRD & Visually attractive areas & [32] & no & yes \\
\hline SHP, GRD & Mariculture & [32] & no & yes \\
\hline SHP, GRD & Unstable geological formations & {$[41]$} & yes & no \\
\hline SHP, GRD & Waste & [41] & yes & no \\
\hline SHP, GRD & Flooding areas & Geoportal of Croatian Waters & no & yes \\
\hline SHP, GRD & Drinking water protection zones & {$[32]$} & no & yes \\
\hline SHP, GRD & $\begin{array}{l}\text { Strategic reserves of } \\
\text { underground water }\end{array}$ & [32] & no & yes \\
\hline \multirow{3}{*}{ SHP, GRD } & Pinna nobilis colonies & [30] & yes & no \\
\hline & Grasslands & {$[30]$} & yes & no \\
\hline & Istrian $\mathrm{Y}$ highway & [30] & yes & no \\
\hline SHP, GRD & Ground prone to erosion (flysch) & [32] & no & yes \\
\hline SHP, GRD & Line of Kanfanar-Rovinj Railway & [6] & no & yes \\
\hline
\end{tabular}

In the case of the bridging longer sections that pass nearby or across the KanfanarRovinj route and simultaneously fit in a wider regional or international context, it is desirable that accommodation suitable for cyclists [44] is located in the immediate vicinity. Thus, it is possible to provide other services tailored to their needs, such as bicycle servicing, and increase the attractiveness of trails. In the case of building new trails that would cross the bay, special attention should be given to their positioning in such a way as to avoid or reduce the negative impact on shellfish farms. Additional factors that were recognized to affect the vulnerability and used in further analysis include: unstable geological structures (troughs); soil type (flysch) and flood areas (due to the potential occurrence of accidents on the track); proximity to the motorway (noise exposure); proximity to the water protection area and strategic groundwater reserves (possible negative impact on groundwater); and habitats that need to be protected (grasslands in the case of inland trails and colonies of the Pinna nobilis shell in the potential organization of trails along the coast where the sea traffic is low (i.e., outside of the port and anchorage areas) [45]. 


\subsection{Analysis}

The inventory analysis of spatial characteristics eligible for cycling and hiking was the key step that preceded the performance of the multicriteria analysis. The previously mentioned data, i.e., cycling and hiking trails, in GPS Exchange format (Figure 3) were used. Their overlap shows the cycling and hiking infrastructure in Istria County. In addition, data on annual cycling and hiking events $[46,47]$ were added in order to identify areas of many types of content and activities for hikers and cyclists on the peninsula.
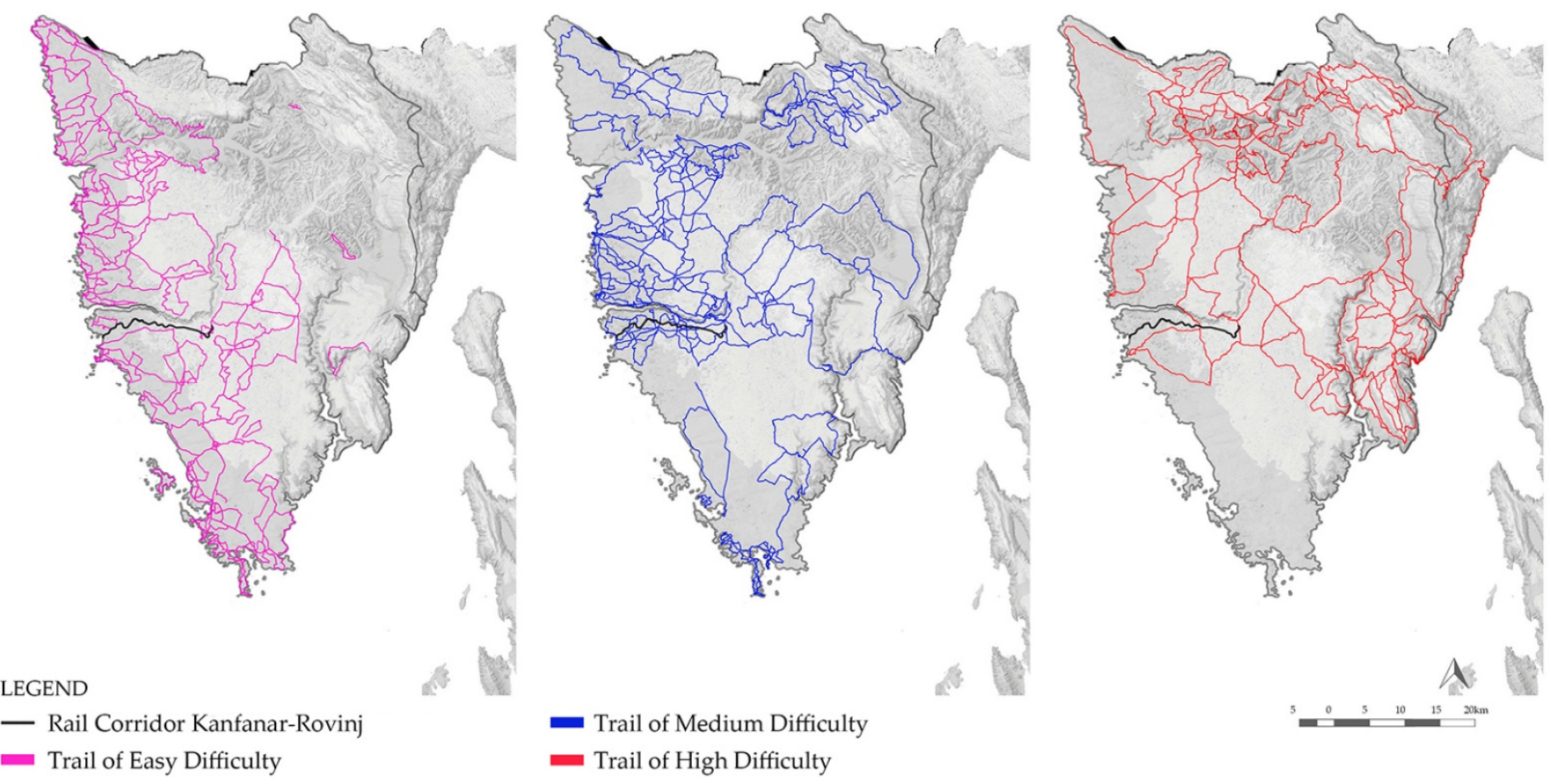

Figure 3. Existing bicycle trails in Istria County.

The obtained areas fulfil the function of paths and nodes that shape the identity of the city [48]. In this research, cycling and hiking trails were assumed to be paths, while accommodation units and events were identified as large-scale nodes. The overlap of spatial data in the GIS interface provided a better insight into their spatial distribution in the territory of Istria County (Figure 4 ).

Furthermore, efforts were made to find possible connections of the abandoned railway to other areas as well. This analysis was performed by using landscape suitability modeling.

The software used for suitability modeling, map overlaying, and making maps of evaluation models was QGIS GIS (2.14.0. with GRASS 7.0.3., QGIS Development Team) and ProVal 2000 (1.1.0.6) [49].

The first step in the modeling process (Figure 5) was to define the dimensions of the cells, i.e., the smallest homogeneous spatial units to which a value on a scale of $1-5$ was attributed.

In landscape research, scales of values from 1 to 5 are mostly used because of their simplicity and also because planners usually tend to use them [50]. Simultaneously, the $10 \times 10 \mathrm{~m}$ cell represents the smallest homogeneous spatial unit and is used to show the classification of the landscape through models of attractiveness and vulnerability. Since bicycle and hiking trails represent recreational activities while accommodation units represent resting and catering points at longer distances, the WLC method [22] was used for the spatial data where a weight factor of 2 was added to them in relation to other factors. In the evaluation of the attractiveness of: (1) ponds and water sources; (2) speleological objects; (3) protected areas of nature and the Ecological Network of Natura 2000; (4) cultural heritage (drywall buildings such as Istrian stone houses ("kazuns") and cassettes, swimming pools, wells, tomb chapels and mausoleums, monuments, and individual archeological sites); 
(5) lookouts and visually attractive areas; (6) bicycle and hiking trails; and (7) tourist accommodation adapted to cyclists, proximity was evaluated as the most attractive, while distance decreased the value (Table 2).

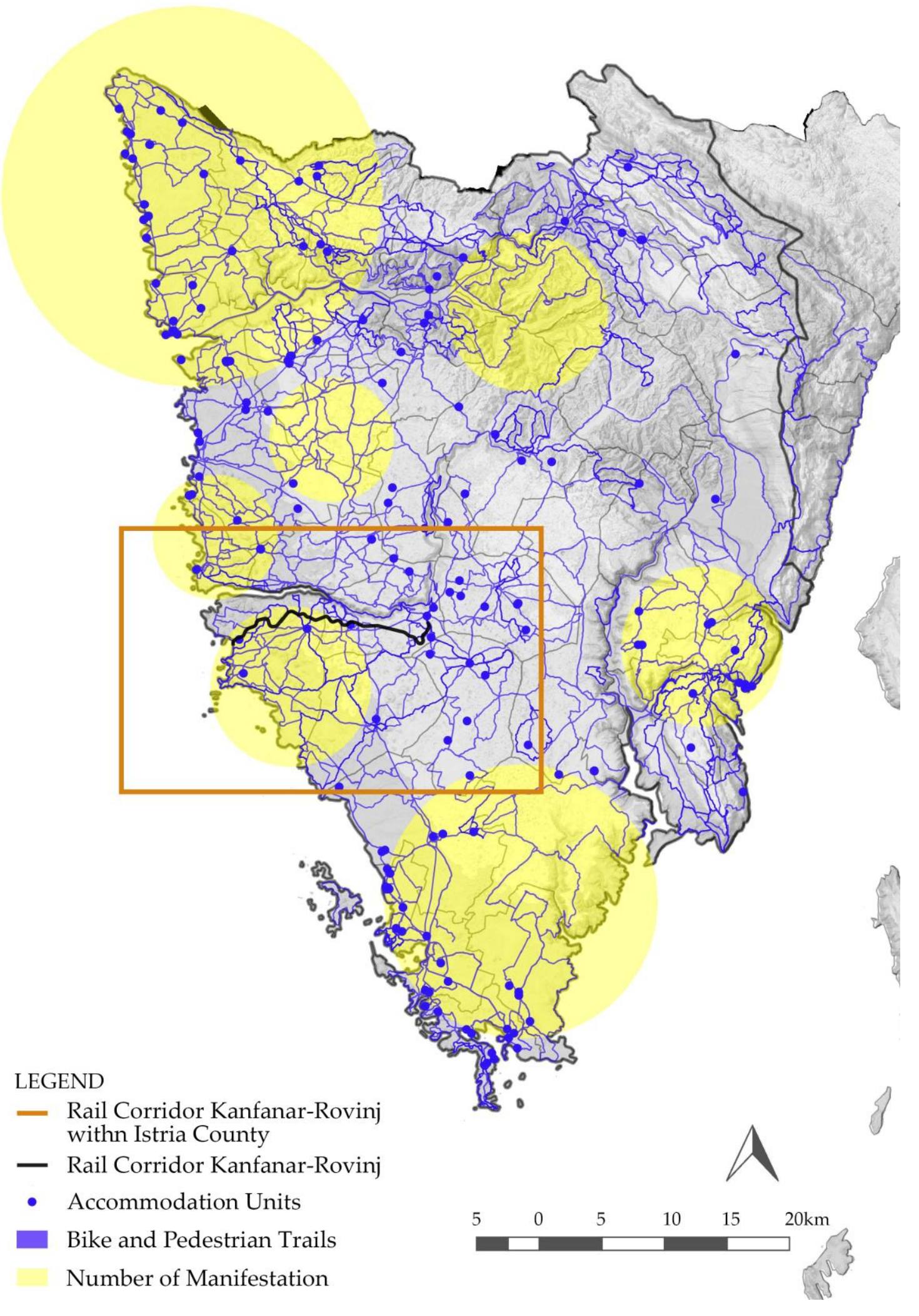

Figure 4. Bicycle and pedestrian trails, accommodation units, and events in Istria County. 


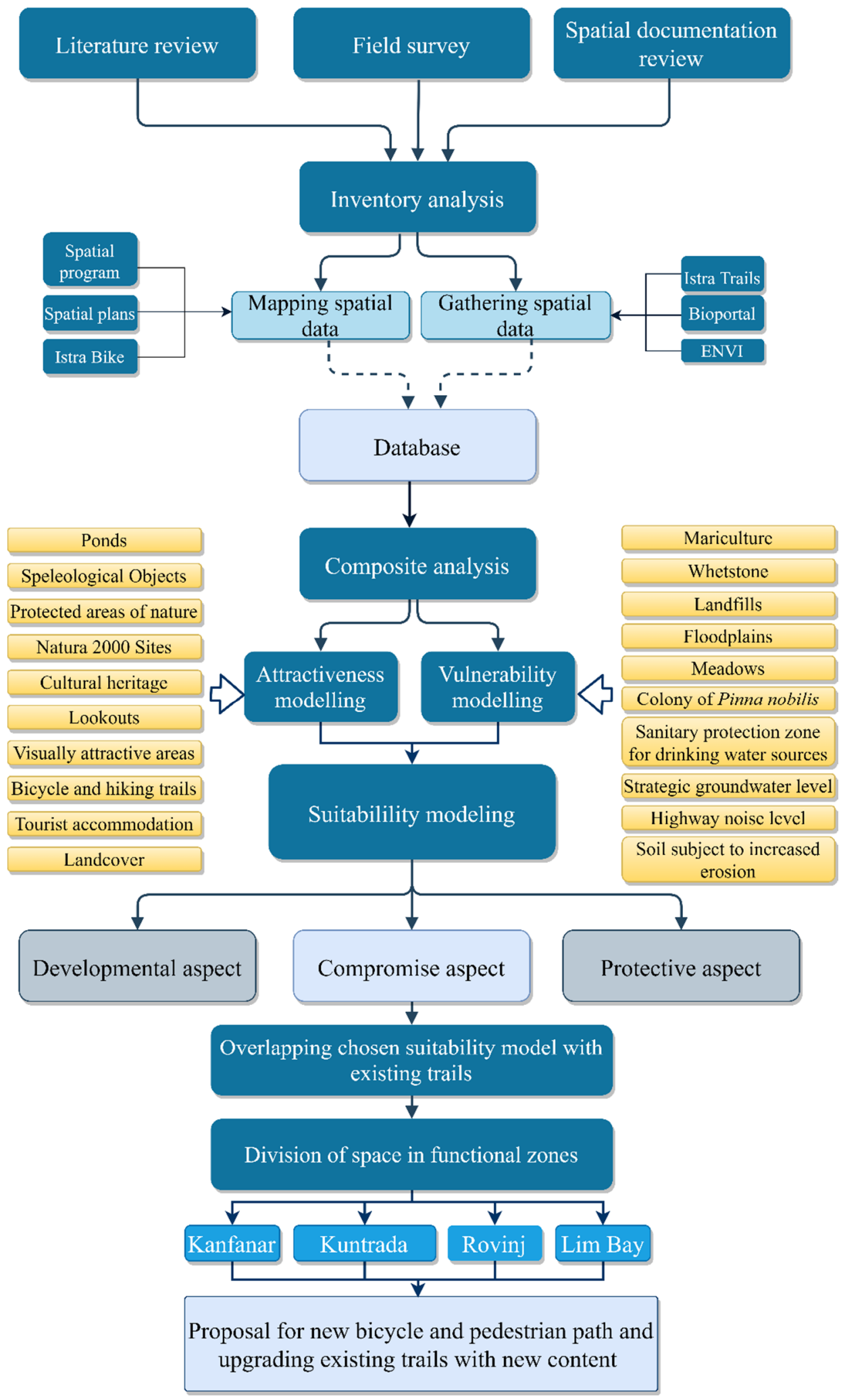

Figure 5. Flowchart of the methodology. 
Table 2. Evaluation of attractiveness.

\begin{tabular}{|c|c|c|c|c|c|c|}
\hline \multirow{2}{*}{$\begin{array}{l}\text { Attractiveness } \\
\text { Factors }\end{array}$} & \multicolumn{6}{|c|}{ Distance Value } \\
\hline & 1 & 2 & 3 & 4 & 5 & $\begin{array}{l}\text { Weight } \\
\text { Factor }\end{array}$ \\
\hline Ponds & $>1000 \mathrm{~m}$ & $500-1000 \mathrm{~m}$ & $250-500 \mathrm{~m}$ & $50-250 \mathrm{~m}$ & $0-50 \mathrm{~m}$ & \\
\hline Speleological objects & $>1000 \mathrm{~m}$ & $500-1000 \mathrm{~m}$ & $250-500 \mathrm{~m}$ & $50-250 \mathrm{~m}$ & $0-50 \mathrm{~m}$ & \\
\hline $\begin{array}{l}\text { Protected areas of } \\
\text { nature and } \\
\text { the Ecological } \\
\text { Network of } \\
\text { Natura } 2000\end{array}$ & $>1000 \mathrm{~m}$ & 500-1000 m & $250-500 \mathrm{~m}$ & $100-250 \mathrm{~m}$ & 0-100 m & \\
\hline Cultural heritage & $>500$ & $250-500 \mathrm{~m}$ & $150-250 \mathrm{~m}$ & $50-150 \mathrm{~m}$ & $0-50 \mathrm{~m}$ & \\
\hline Lookouts & $>400 \mathrm{~m}$ & $200-400 \mathrm{~m}$ & $100-200 \mathrm{~m}$ & 50-100 m & $0-50 \mathrm{~m}$ & 2 \\
\hline $\begin{array}{c}\text { Visually } \\
\text { attractive areas }\end{array}$ & $>600 \mathrm{~m}$ & $400-600 \mathrm{~m}$ & $200-400 \mathrm{~m}$ & $100-200 \mathrm{~m}$ & $0-100 \mathrm{~m}$ & \\
\hline $\begin{array}{l}\text { Bicycle and } \\
\text { hiking trails }\end{array}$ & $>3500 \mathrm{~m}$ & $2000-3500 \mathrm{~m}$ & $1000-2000 \mathrm{~m}$ & $500-1000 \mathrm{~m}$ & $0-500 \mathrm{~m}$ & 2 \\
\hline \multirow[t]{2}{*}{$\begin{array}{c}\text { Tourist } \\
\text { accommodation }\end{array}$} & $>3500 \mathrm{~m}$ & $2000-3500 \mathrm{~m}$ & $1000-2000 \mathrm{~m}$ & 500-1000 m & $0-500 \mathrm{~m}$ & 2 \\
\hline & \multicolumn{6}{|c|}{ Direct evaluation } \\
\hline Land cover & $\begin{array}{l}\text { Industrial or } \\
\text { commercial } \\
\text { units, Port } \\
\text { areas, Mineral } \\
\text { extraction sites }\end{array}$ & $\begin{array}{l}\text { Road and } \\
\text { rail networks } \\
\text { and associated } \\
\text { land, Airports }\end{array}$ & $\begin{array}{l}\text { Discontinuous urban } \\
\text { fabric, Plough land, } \\
\text { Land principally } \\
\text { occupied by } \\
\text { agriculture, with } \\
\text { significant areas of } \\
\text { natural vegetation, } \\
\text { Traditional woodland s }\end{array}$ & $\begin{array}{l}\text { Sport and } \\
\text { leisure facilities, } \\
\text { Permanently } \\
\text { irrigated land } \\
\text { ub }\end{array}$ & $\begin{array}{c}\text { Olive groves, } \\
\text { Vineyards, Forests, } \\
\text { Sea, Meadows, } \\
\text { Pastures, Complex } \\
\text { cultivation patterns }\end{array}$ & \\
\hline
\end{tabular}

It was estimated that for contents that are smaller in size (compared with others) and mostly scattered in the area, the value decreases at smaller distances, while for contents that appear as wider entities in space, the space value decreases at larger distances. The reason for such an approach lies in the assumption that wider and more complex spatial entities can be seen from greater distances, which is not applicable to smaller entities due to their appearance and characteristics. Taking ponds as an example, their benefits, such as visual appearance and microclimate conditions in terms of moisture and freshness, can be perceived only in a narrower area; due to the size of the content, these characteristics rapidly disappear at smaller distances. In the case of wider areas, e.g., protected areas of nature, characteristics of such spaces can still be well-perceived even at larger distances because of the variety of elements that make them recognizable as well as their wider spatial distribution.

When evaluating the lookouts, the method of weighted linear combination was used because the angle of visibility to the overall view of the observed area is higher and the attractiveness of these locations is more pronounced [14].

Some spatial characteristics, such as land cover, were directly evaluated. The method of direct evaluation is used for the evaluation and assessment of the visual quality of the landscape [42]. According to Pires (1993) [51,52], in the direct method the evaluation is realized from the contemplation of the totality of the landscape, by the visualization at the place, or by the use of substitutes (photographs, slides, videos, etc.), giving rise to different levels of subjectivity during the process [51] (p. 2). In this case, different types of land cover were evaluated depending on their visual and perceptive qualities and the functions they may provide to users. For example, meadows were evaluated as the most 
attractive because they provide open and wide views of the surrounding landscape, while forests create the feeling of an enclosed space with its own microclimate and shade, benefits which are pleasantly perceived, especially during summer. In contrast to them, industrial and commercial areas were evaluated as unattractive because they are neither visually attractive nor provide a specific function that could be useful to users in this context, i.e., cyclists and hikers.

When modeling vulnerability, the evaluation was applied through distance classes (Table 3) and which characteristics must be preserved and prevented from further devastation or, if possible, rehabilitated. Vulnerability can also point to certain land uses that prohibit or restrict other activities that could potentially degrade space. This is evident in the example of the mariculture situated along most of the bay [53].

Table 3. Evaluation of vulnerability.

\begin{tabular}{|c|c|c|c|c|c|c|}
\hline \multirow{2}{*}{$\begin{array}{l}\text { Vulnerability } \\
\text { Factors }\end{array}$} & \multicolumn{6}{|c|}{ Distance Value } \\
\hline & 1 & 2 & 3 & 4 & 5 & Weight Factor \\
\hline Mariculture & $>1000 \mathrm{~m}$ & $700-1000 \mathrm{~m}$ & $400-700 \mathrm{~m}$ & $100-400 \mathrm{~m}$ & $0-100 \mathrm{~m}$ & \\
\hline Whetstone & $>1000 \mathrm{~m}$ & $500-1000 \mathrm{~m}$ & $300-500 \mathrm{~m}$ & $100-300 \mathrm{~m}$ & $0-100 \mathrm{~m}$ & \\
\hline Landfills & $0-50 \mathrm{~m}$ & $50-150 \mathrm{~m}$ & $150-250 \mathrm{~m}$ & $250-500 \mathrm{~m}$ & $>500 \mathrm{~m}$ & \\
\hline Floodplains (inland) & $>600$ & $300-600 \mathrm{~m}$ & $200-300 \mathrm{~m}$ & $100-200 \mathrm{~m}$ & $0-100 \mathrm{~m}$ & \\
\hline $\begin{array}{l}\text { Floodplains } \\
\text { (coast side) }\end{array}$ & $>100 \mathrm{~m}$ & 90-100 m & $60-90 \mathrm{~m}$ & $40-60 \mathrm{~m}$ & $0-40 \mathrm{~m}$ & \\
\hline Meadows & $>100 \mathrm{~m}$ & $50-100 \mathrm{~m}$ & $30-50 \mathrm{~m}$ & $10-30 \mathrm{~m}$ & $0-10 \mathrm{~m}$ & \\
\hline \multirow[t]{2}{*}{$\begin{array}{l}\text { Colony of Pinna } \\
\text { nobilis (pen shell) }\end{array}$} & $>500 \mathrm{~m}$ & $250-500 \mathrm{~m}$ & $150-250 \mathrm{~m}$ & 50-150 m & $0-50 \mathrm{~m}$ & \\
\hline & \multicolumn{6}{|c|}{ Direct evaluation } \\
\hline $\begin{array}{c}\text { Sanitary } \\
\text { protection zone } \\
\text { for drinking } \\
\text { water sources }\end{array}$ & $\begin{array}{l}\text { Outside } \\
\text { the zone }\end{array}$ & Restriction zone & $\begin{array}{l}\text { Restriction and } \\
\text { surveillance zone }\end{array}$ & $\begin{array}{l}\text { Strict } \\
\text { restriction zone }\end{array}$ & - & \\
\hline $\begin{array}{c}\text { Strategic } \\
\text { groundwater level }\end{array}$ & - & - & - & - & Entire zone & \\
\hline $\begin{array}{c}\text { Highway } \\
\text { noise level }\end{array}$ & $74-79 \mathrm{~dB}$ & $69 \mathrm{~dB}$ & $64 \mathrm{~dB}$ & $59 \mathrm{~dB}$ & $54 \mathrm{~dB}$ & \\
\hline $\begin{array}{l}\text { Soil subject to } \\
\text { increased erosion }\end{array}$ & - & - & Flysch & - & - & \\
\hline
\end{tabular}

Besides the visual perception of landscapes, people also experience landscapes through the sense of hearing [54] (p. 13). In the case of the proximity of highways A8 and A9, i.e., the Istrian $Y[41,55]$, except for not being a visually attractive element, it decreases the value of the space because of sound pollution. Since sound is an integral part of the perception of a space, the method of direct evaluation was applied to different sound thresholds for the indicator Lden, where the abbreviation den indicates day-evening-night. The reason for choosing Lden instead of Lday lies in the fact that some manifestations take place in the evening or even during the night $[46,47]$. Taking into account the fact that intense sound is not pleasantly perceived, it was evaluated as invulnerable.

After the suitability model was obtained, more detailed analyses of the zones with the highest suitability (zones 4 and 5) were performed. For the purpose of a better understanding, functional zones were formed. Depending on the spatial combination of contents, the 'thematization' of new bicycle and pedestrian paths to be located in their space was performed. The selection of content to be included in the trail system was made on the 
basis of its affiliation with natural, cultural-historical, and visual-experiential qualities (Table 4).

Table 4. An overview of functional areas with selected contents and their qualities.

\begin{tabular}{|c|c|c|c|c|}
\hline \multicolumn{2}{|c|}{ Landscape Elements } & \multirow{2}{*}{$\frac{\text { Natural }}{+}$} & \multirow[t]{2}{*}{ Cultural-Historical } & \multirow{2}{*}{$\begin{array}{c}\text { Visual-Experiential } \\
+\end{array}$} \\
\hline Functional Area & Pits & & & \\
\hline \multirow[t]{4}{*}{ Kanfanar } & Springs & + & & + \\
\hline & Lookouts & & & + \\
\hline & Abandoned Railway Facilities & & + & \\
\hline & Forest Paths & & & + \\
\hline Functional Area & Ponds & & + & + \\
\hline \multirow[t]{2}{*}{ Kuntrada } & Drystone buildings & + & + & + \\
\hline & Lookouts & & & + \\
\hline Functional Area & Churches & & & + \\
\hline \multirow[t]{2}{*}{ Rovinj } & Lookouts & & + & + \\
\hline & Forest Paths & & & + \\
\hline Functional Area & Lookouts & & & + \\
\hline Lim Bay & Protected Areas of Nature & + & & + \\
\hline
\end{tabular}

The selection of criteria for the relevant content selection was implemented with aspects used in previous research: natural, cultural-historical, and visual-experiential qualities [50,56,57].

Natural qualities were met by protected areas of nature, the Natura 2000 Ecological Network, and geomorphological sites. According to the Nature Protection Act [58], protected natural areas make up a geographically clearly defined area that is managed for the long-term preservation of nature and accompanying services of the ecological system and whose value is measured by its presence and size $[50,59]$. Geomorphological sights include speleological objects, ponds, and springs whose value is related to the diversity of species and habitats $[50,60]$. Speleological objects were selected on the basis of an impressive appearance (Kumbašeja Pit, the pit near the village Burići) [17]. Ponds form an important part of the rural landscape and represent a small and enclosed aquatic habitat of natural, semi-natural, or artificial origin [61]. They once served as a water supply, but today they represent one of the greatest values of biological and landscape diversity of the areas in which they are located [17]. In general, authors argue that water elements in all their forms represent an attraction in the space in which they are located; it is a known fact that human civilization throughout history established its settlements near water elements, which are the source of life [62]. This can be seen in the example of the Kašteljir water source near Kanfanar, to which the first mention of the settlement is connected.

The visual-experiential criterion is unique because it enables the connection of a person with the landscape. The notion of 'landscape' depends on an individual's view, perception, and personal and collective identification with nature [63-67].

When selecting content with visual-experiential qualities, an attempt was made to perform a perceptual assessment $[50,68]$. Thus, on the example of forest paths, it is possible to feel the naturalness, the intimacy of the space, the silence, the smell of the forest, and the shade. Numerous authors, such as Norton et al. 2012, point out the potential that the forest has for recreation at the national level $[67,69]$, which is all the more pronounced due to the fact that many foreign guests (among them pedestrians and cyclists) come on vacation during the summer months, according to the data provided by the Croatian National Tourist Board [70], when the forest shade is particularly positively perceived due to high temperatures.

A similar situation arose with protected natural areas, especially the Lim Bay, which, due to the developed relief, the diverse land cover, and the presence of the sea, has been recognized as a space with a special aesthetic atmosphere and an important tourist and recreational point [20]. Within the Lim Bay, lookouts stand out as strategic points from which views of a diverse character on the bay area are provided [17]. 
The cultural potential was evaluated through the presence of prehistoric drystone buildings on the territory of the Kanfanar municipality [71] as well as cultural heritage buildings located north of Rovinj.

During the selection of historic buildings, their good preservation was an important factor, since they represent the testimony of certain historical periods $[50,68]$. In the context of traditional architectural heritage, drystone structures have been singled out [17]. Among them, the so-called 'hill forts' represent a primary form of settlement [71].

\section{Results}

The suitability model that emerged from the overlap of the attractiveness and vulnerability models was generated considering development, protective, and compromise aspects [20,72]. Depending on the strategic vision for an area, one of these three aspects was selected.

Comparing all three aspects of suitability (Figure 6, Table 5), it is evident that the development aspect offers the most developmental opportunities to connect the railway to the surrounding spatial potentials. A comparison of the development and protective aspects shows that the obtained classes spatially overlap, but in a way such that the overall value of the space is classified with a lower grade (Figure $6 a, b)$.

a
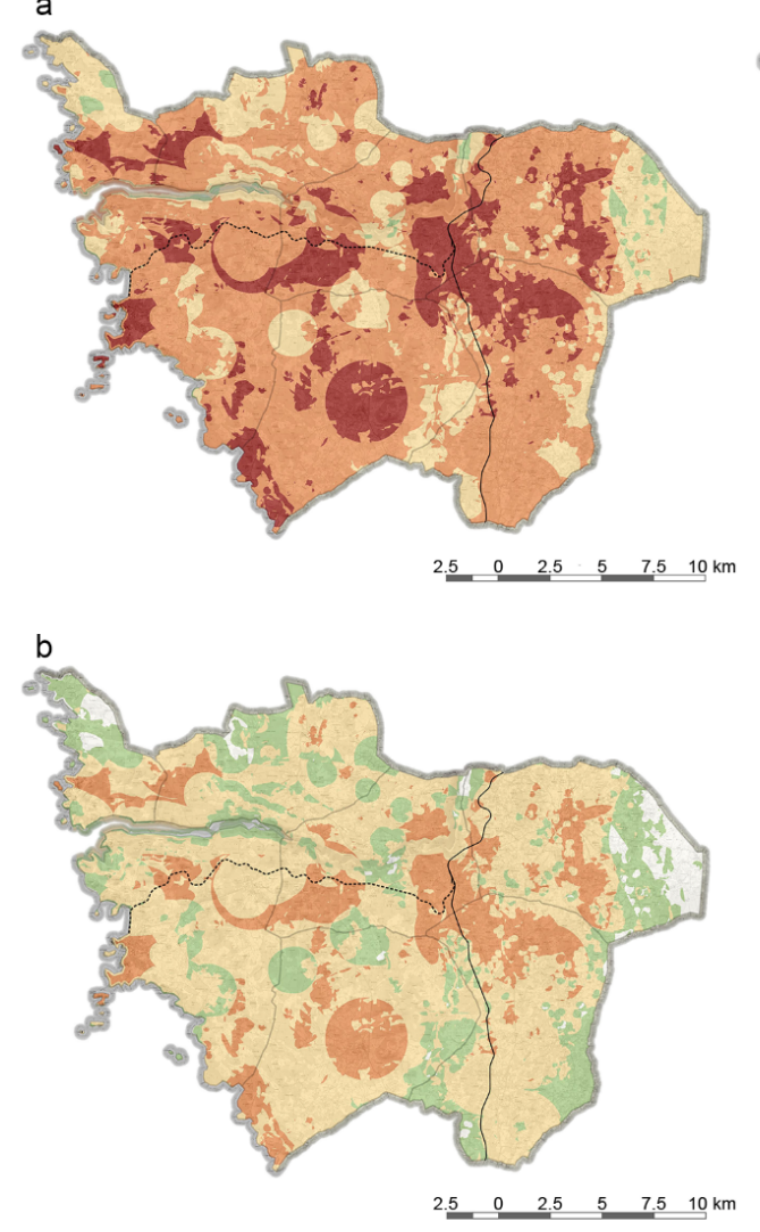

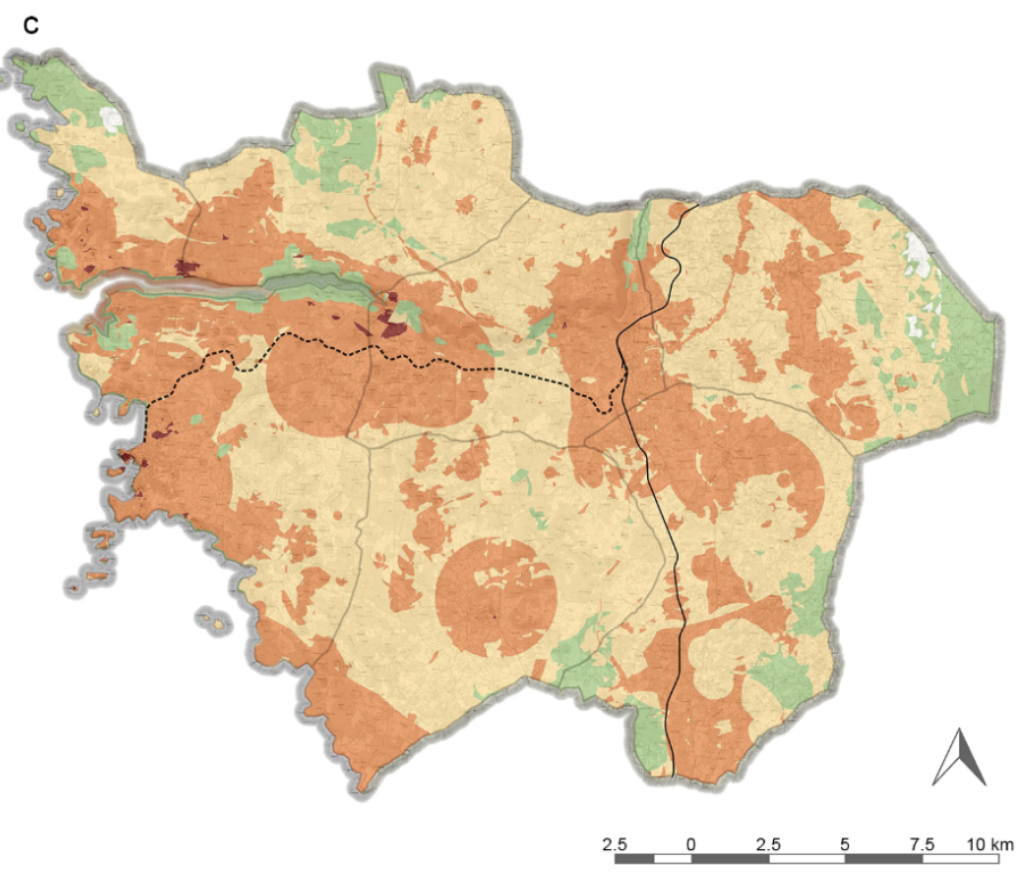

LEGEND

..... Kanfanar - Rovinj Corridor

- R101 Rail Corridor

Borders between Municipalities

Suitability Value

1 - Unsuitable

2 - Marginally Suitable

3 - Medium Suitable

4 - Very Suitable

5 - The Most Suitable

Figure 6. (a) Development aspect of the suitability model; (b) Protective aspect of the suitability model; (c) Compromise aspect of the suitability model. 
Table 5. A comparative view of the suitability value for bike and pedestrian path planning.

\begin{tabular}{|c|c|c|c|c|}
\hline & Suitability Value & $\begin{array}{c}\text { Protective Aspect } \\
\text { Area in } \%\end{array}$ & $\begin{array}{c}\text { Development Aspect } \\
\text { Area in } \%\end{array}$ & $\begin{array}{c}\text { Compromise Aspect } \\
\text { Area in \% }\end{array}$ \\
\hline 1 & Unsuitable & $12 \%$ & / & $3 \%$ \\
\hline 2 & $\begin{array}{l}\text { Marginally } \\
\text { suitable }\end{array}$ & $33 \%$ & $6 \%$ & $24 \%$ \\
\hline 3 & $\begin{array}{l}\text { Medium } \\
\text { suitability }\end{array}$ & $32 \%$ & $31 \%$ & $36 \%$ \\
\hline 4 & Very suitable & $23 \%$ & $34 \%$ & $31 \%$ \\
\hline 5 & The most suitable & / & $29 \%$ & $6 \%$ \\
\hline
\end{tabular}

Since the compromise aspect of suitability combines the features of both the development and protective aspects, in this study it was selected as a reference sub-model that helped with finding very and the most suitable locations for the connection of the new bike path to the surrounding context. An additional reason is that the analysis of the compromise model revealed a better spatial distribution of very and the most suitable areas (Figure 6c).

The Kanfanar functional area showed a high degree of suitability and potential because its trail connects very diverse contents: speleological objects (pits), water sources, railway heritage, and lookouts. Thanks to the unchanging microenvironment, speleological objects contain enormous biodiversity [73] and are connected to the Natura 2000 network through the surrounding green system. The value of the entire area is further enhanced by the abandoned railway facilities at the very beginning of the line, where the possibility of conversion and revitalization has been identified (Figure 7).

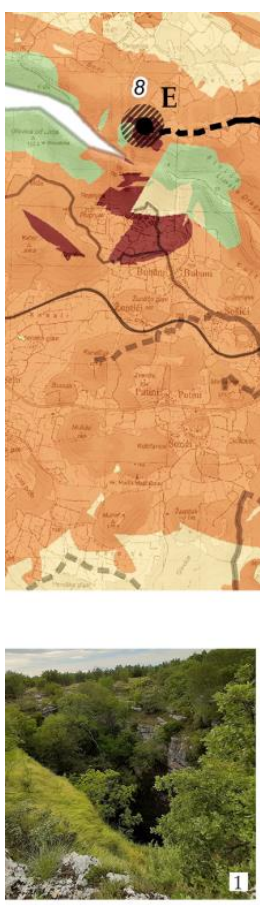

Locations:

1 - Kumbašeja Pit

2 - Natura 2000 Site (Source: Dvegrajci)

3 - Abandoned Railway Facility

4 - Forest Path

5 - Castle Lookout

6 - Periodically active Water Spring

7 - 13th century Monument

8 - Lim Bay Lookout
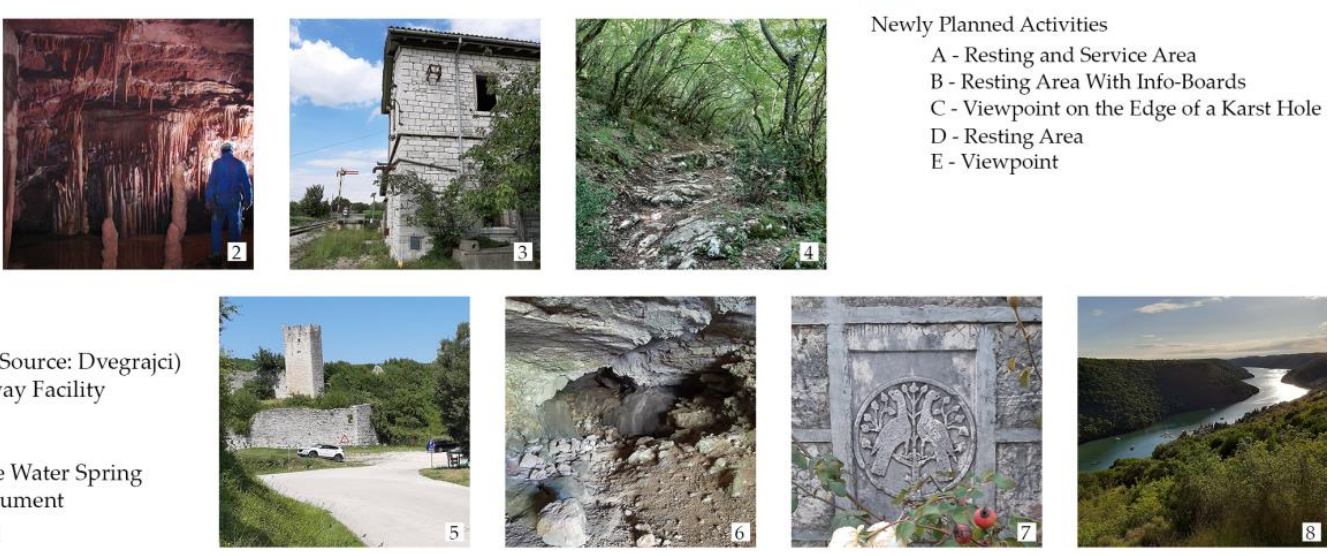

Figure 7. The Kanfanar functional area. 
The second functional area (Kuntrada) covers the central part of the railway and is characterized by elements of the traditional rural landscape, such as drystone buildings and ponds.

While prehistoric drystone buildings are located in an imposing position at the top of the hill [74], the ponds are mostly scattered along existing roads. Ponds are an integral and important part of the rural landscape and at one time were used both to feed livestock and for human consumption [17]. Thanks to their historical, ecological, and aesthetic significance, it is necessary to protect them in order to prevent further degradation (Figure 8).

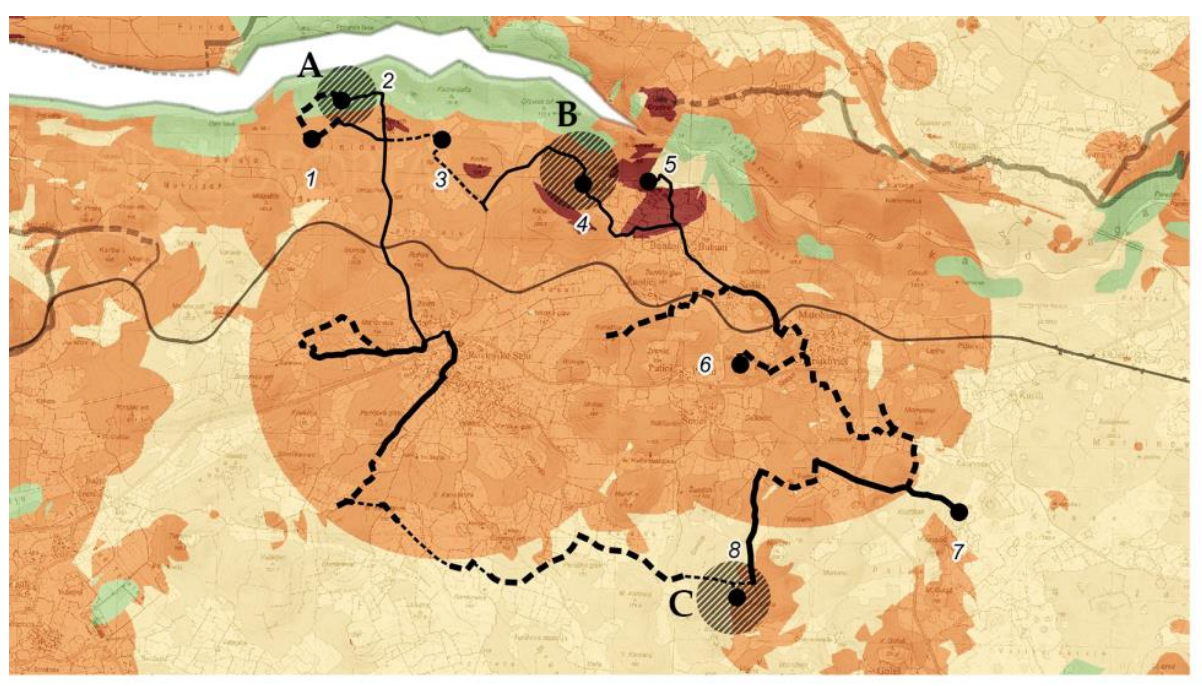

LEGEND
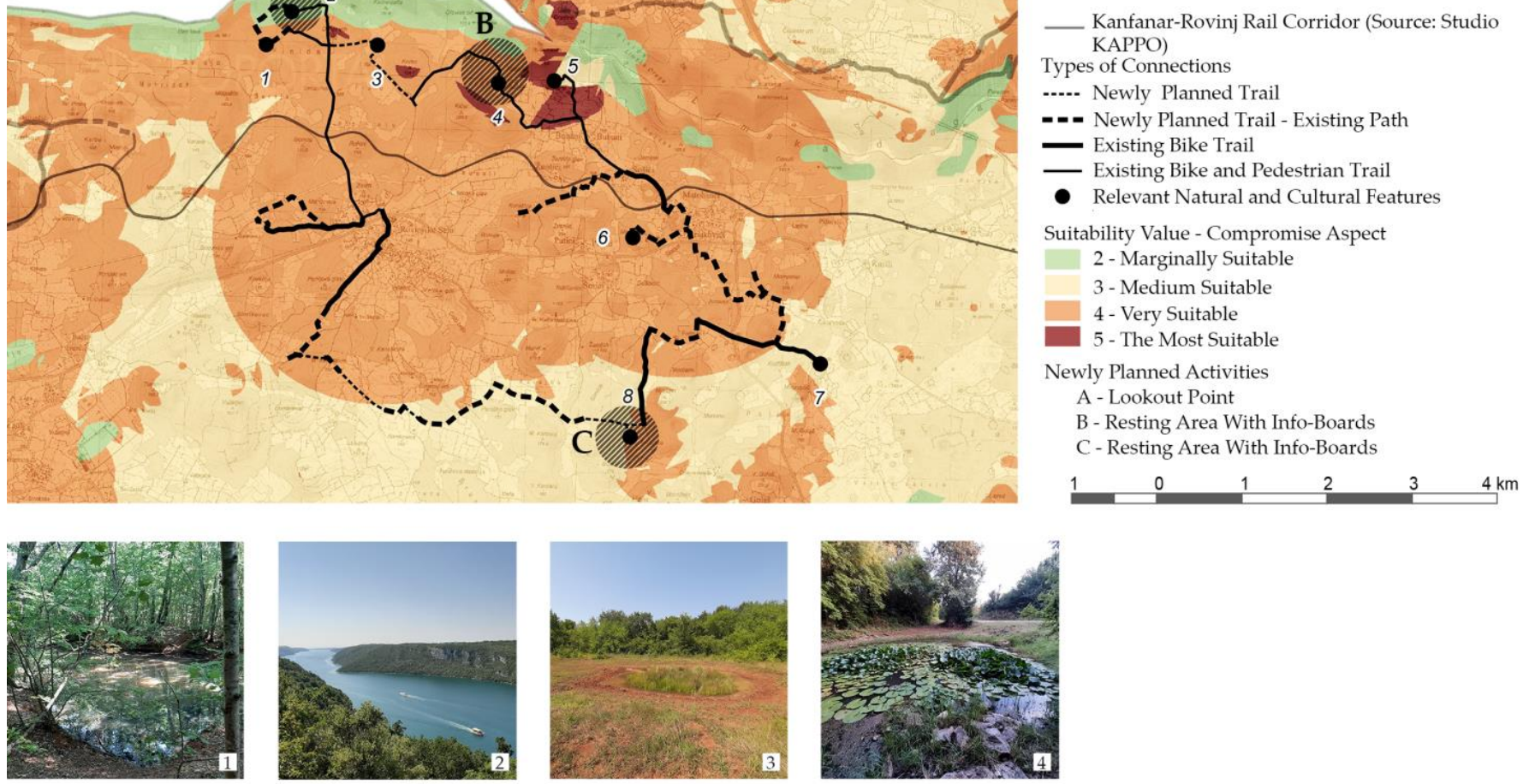

Locations:

1 - Lokvina Pond

2 - Drčev Vrh Lookout

3 - Drčevica Pond

4 - Biličinka Pond

5 - St. Martin Lookout

6 - Tumulus on a hilltop Maklavun

7 - Old Pond

8 - Pond near Pasjak
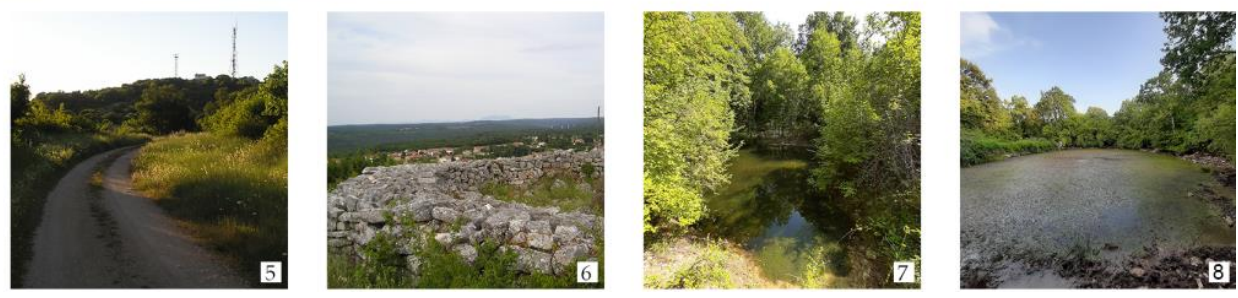

Figure 8. The Kuntrada functional area.

Lookout locations represent potential points with different characteristic views of the protected area of Lim Bay and Valley. From Drčev Vrh, there is a wide view of the central part of the bay and, on St. Martin, the view extends over the slopes of Lim Valley all the way to the Učka massif (Figure 9). It should be noted that the wider area of the St. Martin lookout is also the largest area, which was evaluated as the most suitable.

The character of the third functional area (Rovinj) is defined by views from strategic points on the outskirts of the city towards the old town of Rovinj and the tower of the church of St. Euphemia. In the northern part of the rural hinterland, there are several churches from the Romanesque period [75]. Most of them are easily accessible from the pedestrian and bicycle paths. The church of St. Thomas stands out as the only historical and cultural element located along the railway [6]. The additional potential of the space lies in the existing network of pedestrian and bicycle paths (Figure 10). 

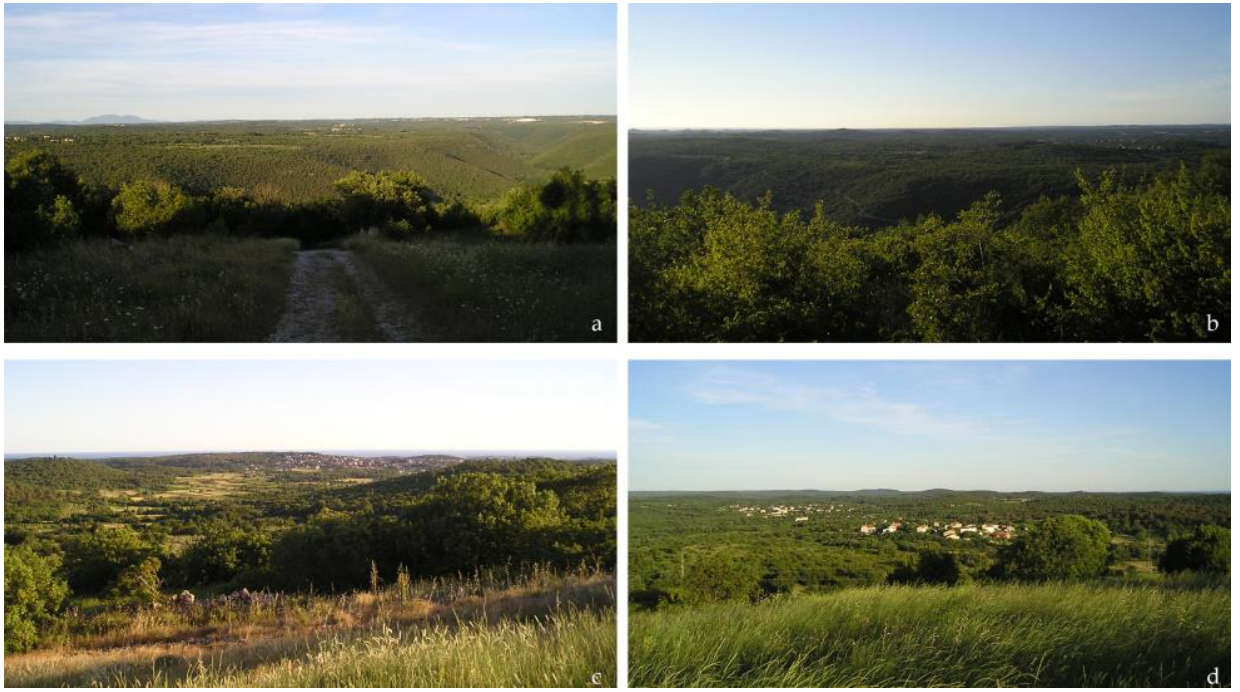

Figure 9. Views from the viewpoint of St. Martin to the: (a) east; (b) north; (c) southwest; and (d) south.

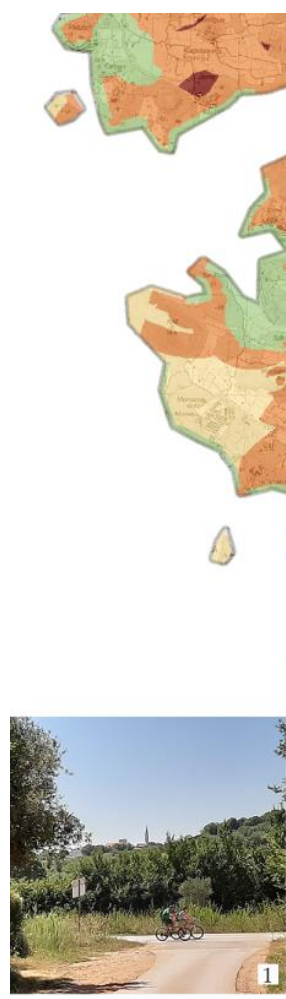

Locations:

1 - Church Tower as Landmark

2 - St. Christopher's Church

3 - St. Bartholomew's Church

4 - Forest Path

5 - St. Protus's Church

6 - St. Thomas Church

7 - Railway Bridge

8 - Railway embankment
LEGEND

_ Kanfanar-Rovinj Rail Corridor (Source: Studio KAPPO) Types of Connections

Newly Planned Bridge $(830 \mathrm{~m})$

-..-. Newly Planned Trail

-- - Newly Planned Trail - Existing Path

- Existing Bike Trail

— Existing Bike and Pedestrian Trail

- Abandoned Railway Bridge

- Relevant Natural and Cultural Features

Suitability Value - Compromise Aspect

2 - Marginally Suitable

3 - Medium Suitable

4 - Very Suitable

5 - The Most Suitable

Newly Planned Activities

A - Resting Area with Info-Boards

B - Signpost Towards Lim Bay

C - Resting Area

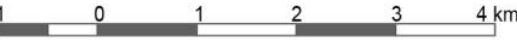

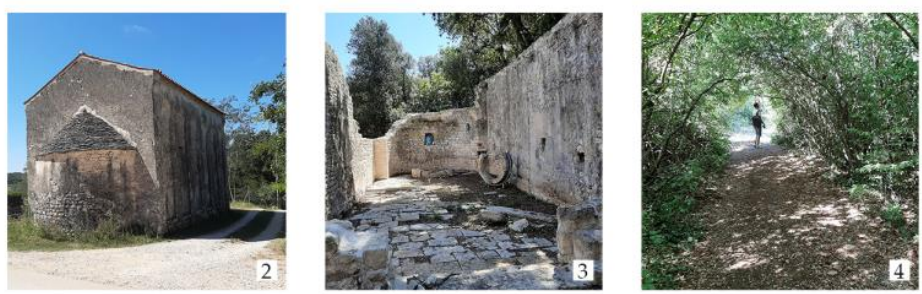
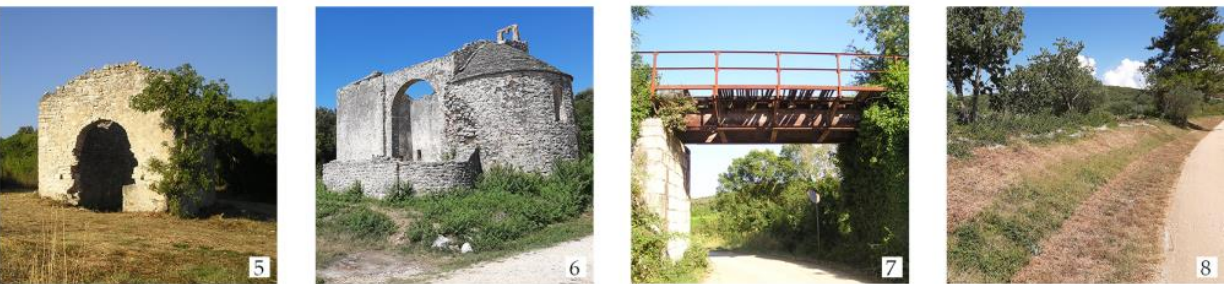

Figure 10. The Rovinj functional area.

Moving north, it can be seen that the belt of very suitable areas extends across the sea part of the bay to the northern mainland (the Lim Bay functional area). The marine part of the bay is an exceptional aesthetic-perceptual and natural area subject to protection 
due to the preservation of its uniqueness, rarity, and representativeness [30]. This area enables a diverse view of the area, from the sea to the mainland of the bay, which would be achievable through the implementation of pedestrian communications across the Lim Bay, which Paljar et al. call "pedestrian routes at sea" [17]. By connecting pedestrian and bicycle communications located on both sides of the bay, it would be possible to bridge the natural border and at the same time connect the north and south sides of the peninsula, creating opportunities for social and economic benefits from developing ecotourism (Figure 11).
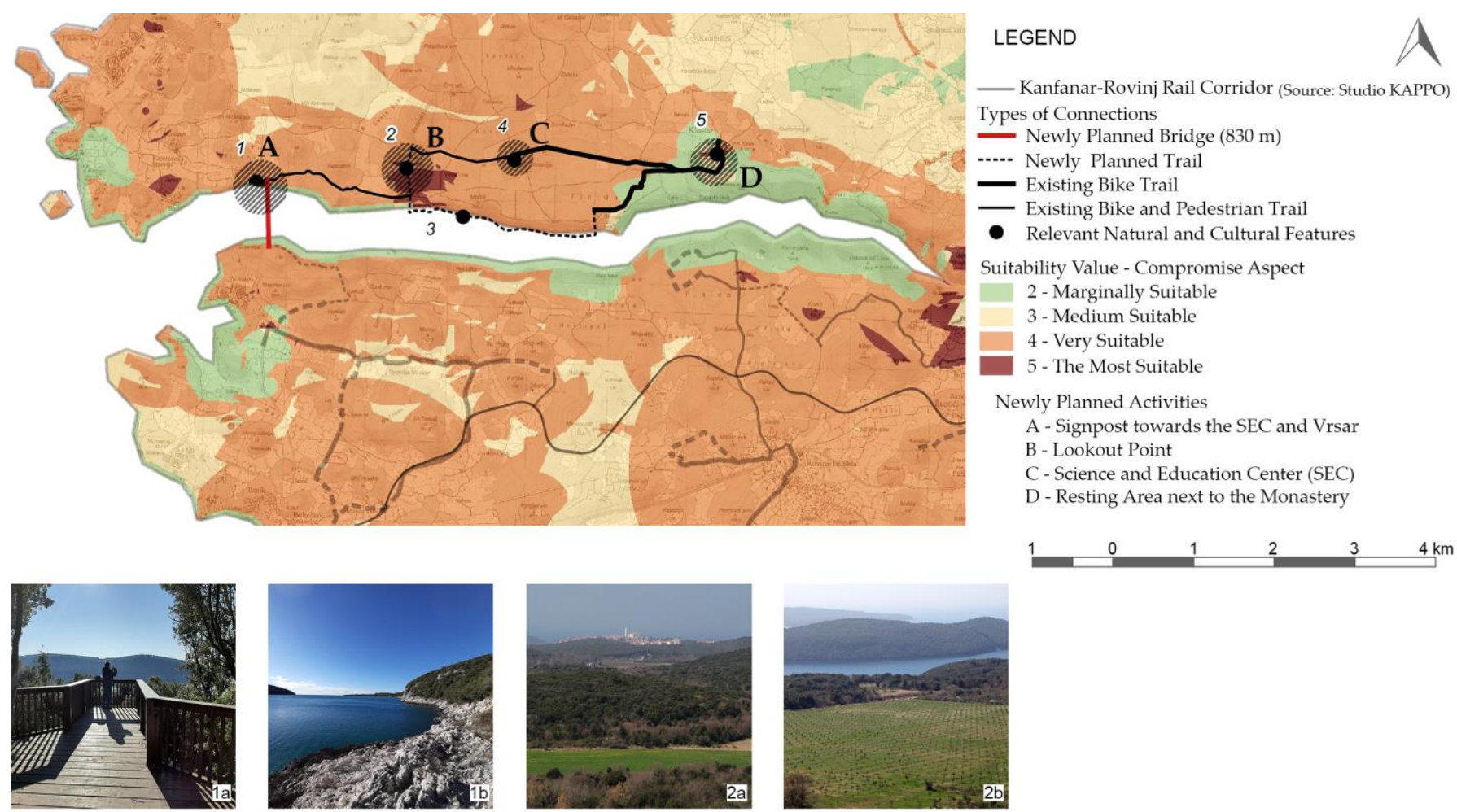

Locations:

1a - Crljenka Lookout

$1 \mathrm{~b}$ - View on Lim Bay Mouth

2a - West View (Source: Izleti po Istri)

$2 \mathrm{~b}$ - South View (Source: Izleti po Istri)

3 - Northern Lim Bay Coast

4a-SED Building under construction

$4 \mathrm{~b}$ - Resting Area

5 - 10th century Monastery
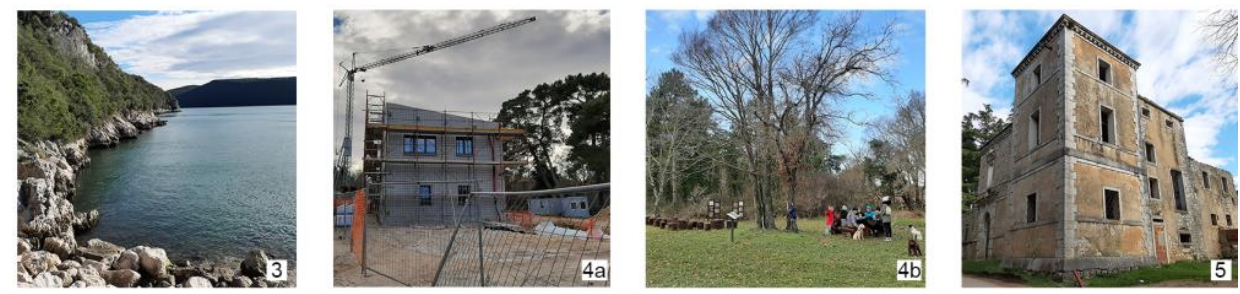

Figure 11. The Lim Bay functional area.

\section{Discussion}

In this study, it can be seen that approaches to evaluating attractiveness and vulnerability differ. Due to the depth of spatial visibility in the model of attractiveness, the highest values were attributed to small distances. However, this was not the case in the vulnerability model, where an evaluation was possible only after the character of the landscape was determined, i.e., whether it is a critical point, vulnerable, or a zone of restriction and protection. The result of such an approach to evaluation is clearly shown in the spatial suitability model, where the spatial distribution of classes varies depending on the evaluation principle applied to each aspect.

The compromise aspect represents a balance in which both the development and protective aspects of space meet. The basis of this approach is that the planning of new pedestrian and bicycle paths will not significantly degrade the existing landscape and natural qualities, but will improve them if existing potentials are used in a sustainable way. 
Although the most suitable areas are very few in number, they still play a key role in the attractiveness of the wider area along the railway. From the map of the compromise aspect of the suitability model, it can be seen that the belt of very suitable areas along the railway is very irregular and fragmented, and its range varies from 1.5 to $6.5 \mathrm{~km}$ in distance.

The topic of the conversion of the abandoned Kanfanar-Rovinj railway into a bicyclepedestrian path has been discussed before [6], but a different approach was applied. When creating the program's concept, the authors considered the area of influence of the railway in a $1 \mathrm{~km}$ zone around the railway with the intention of integrating the wider area, including its tourist offerings and various facilities throughout the redevelopment process [6].

The authors used a hybrid of a structural analysis and a multicriteria analysis. In the application of the method of direct evaluation, the physical break between roads and railways was a critical point, while the surrounding area was not taken into consideration. Such a analysis achieved a clear polarization of content to potentials and problems, but part of the vulnerability and attractiveness classification was missing.

The fact that there was no classification of content potentially confirms the thesis that the authors attached equal importance to all spatial contents, which can be inferred from the following quote: " ... with integrated approach and creating synergy between different contents, needs and practices in railways, it is possible to create the foundations for its future active use and thus contribute to the comprehensive enrichment and revitalization of the area that stretches along railway. It is precisely with this approach that it is possible to increase interest in cycling and increase the level of bicycle use as a sustainable means of transport for everyday purposes" [6,76].

Given the larger spatial coverage and its complexity, the example presented in this paper shows that classification needs to be a priority in order to obtain a qualitative overview of the most suitable zones for developing greenways connecting protected natural areas and the ecological network to the railway corridor. An interpretation of the most suitable zones showed that all selected contents meet the criterion of multifunctionality. In order to take further steps in planning, multicriteria analysis requires a supplement for the purpose of making strategic decisions related to the more detailed development of selected parts of the space.

This can be achieved by an analysis of the planned land use, but also field research in which the planner uses an expert assessment to identify spatial potentials that have previously gone unnoticed, i.e., conversion of abandoned railway facilities or opening scientific-educational centers [6,17]. In the case of scientific-educational centers, the formation of important information-education hubs raises the value of the space, while abandoned railway facilities have great potential for conversion into future service hubs. Such a move would initiate the process of sustainable development by involving the local population [77] but also enriching services for pedestrians and cyclists in a (broader) regional context.

The Spatial Development Strategy of the Republic of Croatia [78] emphasizes that such protected areas should become the focal points of new rural strategies. Implementation of such a proposal could be done through the design of regional tourist routes that are part of the operational strategy of the Touring System of Istria [79]. The essence of such a network is that the user comes to know the natural and cultural sights of the peninsula, with emphasis on the importance of the elements included in the analysis: resting areas, lookouts, educational centers, and contemplation and break points. Although the touring system in the context of the Master Plan of Tourism of Istria 2015-2025 [79] includes road infrastructure, the same applies to the bicycle-pedestrian path, which was implemented in this paper through the proposal of new educational and resting points and lookouts. In addition, the development strategy and the tourism master plan encourage the use of strategic objectives (inventory and equipping and improvement of the existing system of pedestrian and bicycle paths) in order to activate the brownfield area and reuse derelict infrastructure through new and sustainable forms of use [78,79]. 
In the case study, most of the data layers were collected through a field inventory and the available databases. Therefore, the results may have been affected by the quality of the gathered data. This paper confirms previous research conclusions $[23,24]$, which state that detailed land cover with a minimum-size cell-enhanced multicriteria analysis results in more precise and better-oriented solutions for a specific greenway location.

In the spirit of strategic spatial thinking based on the harmonization of different development and protection requirements, landscape suitability modeling shows many advantages. It is impossible to plan each land use individually and only from the aspect of attractiveness (and cost-effectiveness) for a particular activity. When planning strategically, a vision for the development of a certain area is necessary when determining priorities. The suitability model does not imply that all proposed locations are ideal; however, guided by fuzzy logic [22,25], the models provide insight into suitability classifications (from more to less suitable). The strategic concept of development, existing land use, and other interventions that are planned in the area must be considered as well. In fact, some areas have great potential for the use of natural resources, so modeling may prove them suitable for more than one intervention, which can easily lead to conflict. In the subsequent decision-making process, it is important to determine priorities and examine other suitable locations based on the vision of development in order to determine which of the planned interventions has priority in a particular location and strive to allocate all planned interventions in the most suitable locations. That is why the models of suitability, vulnerability, and attractiveness obtained by the method of weighted linear combination cannot be considered final in decision-making. These models provide the optimal proposal and constitute a guiding factor that must be further verified and harmonized with other interests, with the aim of sustainable spatial development.

\section{Conclusions}

The intention of conducting a multicriteria analysis was to evaluate an area in order to gain better insight into its suitability for establishing new bicycle and pedestrian paths by using old railway lines and existing unused infrastructure. The advantage of this method is that the planner can at any time identify potentially valuable elements in the space and integrate them into the evaluation system. In this case, this is visible in the example of the weighting of lookouts, existing hiking and biking trails, and accommodation units for the reason that they significantly contribute to the attractiveness and quality of the trail and encourage cycling and hiking in general. The result of the multicriteria analysis was a suitability model that was then used to gain insight into three aspects: development, protection, and compromise. Depending on the character of the space, but also on the typology of the plan or project that is being carried out, it is possible to opt for a particular model. Given the complexity of the space, this paper proceeded to the process of forming functional zones within very and the most suitable areas in order to identify and analyze the potentials of specific locations. The analysis of the selected potentials shows that the condition for selecting each of them was to satisfy different qualitative criteria (natural, cultural-historical, and visual-experiential), which allow for a view of a narrower space from several different aspects and thus provide a better understanding. This process was a key factor in locating links-new and reused cycle paths-between the railway corridor and significant spatial areas, such as protected areas and the Natura 2000 ecological network. The goal was to make the proposed connection a starting point for the local community in conserving and repairing urban and rural areas by a holistic approach. The multifunctional role of greenways in solving problems and adding ecological, recreational, and cultural-historical functions in the network of corridors is perhaps the most acceptable approach. Visible in the context of protected natural areas, the connection seeks to contribute to a greater influx of users and their circulation between these significant spatial areas, principally because of the importance they represented in the past to the local community. Revitalization of the abandoned railway and its connection to the surrounding landscape may have a dual, equally positive impact that is defined 
in the Development Strategy of the Istrian County [80]: the conversion of brownfields will achieve the restoration of rural areas that will generate the development of economic activities [81], while the connection to natural and cultural-historical potentials will attract those users who appreciate the local identity and quality in the experience of space.

Author Contributions: Conceptualization, A.M., M.K., and D.T.R.; methodology, A.M. and D.T.R.; software, A.M.; formal analysis, A.M. and D.T.R.; investigation, A.M.; resources, A.M. and D.T.R.; data curation, M.K.; writing-original draft preparation, A.M.; writing-review and editing, M.K. and D.T.R.; visualization, A.M. and M.K.; supervision, M.K. All authors have read and agreed to the published version of the manuscript.

Funding: This research received no external funding.

Data Availability Statement: The data that support our research findings are available from the corresponding author on request.

Conflicts of Interest: The authors declare no conflict of interest.

\section{References}

1. Blackwell, C.C. After use of surplus railway land. Landsc. Res. 1977, 2, 4-6. [CrossRef]

2. Rovelli, R.; Senes, G.; Fumagalli, N.; Sacco, J.; De Montis, A. From railways to greenways: A complex index for supporting policy making and planning. A case study in Piedmont (Italy). Land Use Policy 2020, 99, 104835. [CrossRef]

3. Orbanić, J. Cars in Istria. In Traffic in Istria: From Argonauts to Ipsilon, 1st ed.; Bratulić, J., Cvek, E., Ladavac, A., Anzur, A., Maras, I., Mirković, M., Eds.; C.A.S.H.: Pula, Croatia, 2005; p. 86.

4. Rovinj Heritage Museum. Available online: http://admindogadaji.muzej-rovinj.hr/UserFiles/Dogadaj/1046/Katalog.pdf (accessed on 26 April 2021).

5. Official Website of Region of Istria. Economy. Available online: https://www.istra-istria.hr/en/region-of-istria/generalinformation/economy/ (accessed on 22 November 2020).

6. Studio za Krajobraznu Arhitekturu, Prostorno Planiranje, Okoliš d.o.o. The Concept Design of Conversion of the Abandoned Railway Kanfanar-Rovinj INTO a Bicycle-Pedestrian Path; Studio za Krajobraznu Arhitekturu, Prostorno Planiranje, Okoliš d.o.o: Rovinj, Croatia, 2019; Available online: https:/ / www.kanfanar.hr/wp-content/uploads/2020/02/IDEJNO-RJE\%C5\%A0ENJE-prugaKanfanar-Rovinj.pdf (accessed on 26 April 2021).

7. Pekin Timur, U.; Özden, E.; Erzin, P.E.; Timur, Ö.B. Investigation of Çankıri City Railway in Scope of Greenway. Sustainability 2021, 13, 3055. [CrossRef]

8. Zhang, C.; Dai, S.; Xia, H. Reuse of Abandoned Railways Leads to Urban Regeneration: A Tale from a Rust Track to a Green Corridor in Zhangjiakou. Urban Rail Transit 2020, 6, 104-115. [CrossRef]

9. DiRuocco, G.; Sicignano, E.; Fiore, P.; D’Andria, E. Sustainable Reuse of Disused Railway. Procedia Eng. 2017, 180, 1643-1652. [CrossRef]

10. Groome, D. "Green corridors": A discussion of a planning concept. Landsc. Urban Plan 1990, 19, 383-387. [CrossRef]

11. Gandy, M. Unintentional landscapes. Landsc. Res. 2016, 41, 433-440. [CrossRef]

12. Pena, S.B.; Abreu, M.M.; Teles, R.; Espírito-Santo, M.D. A methodology for creating greenways through multidisciplinary sustainable landscape planning. J. Environ. Manag. 2010, 91, 970-983, ISSN 0301-4797. [CrossRef]

13. Ferretti, V.; Degioanni, A. How to support the design and evaluation of redevelopment projects for disused railways? A methodological proposal and key lessons learned. Transp. Res. D Transp. Environ. 2017, 52, 29-48. [CrossRef]

14. Eizaguirre, A.; Grijalba, O. A methodological proposal for the analysis of disused railway lines as territorial structuring elements: The case study of the Vasco-Navarro railway. Land Use Policy 2020, 91, 104406. [CrossRef]

15. Noh, Y. Does converting abandoned railways to greenways impact neighboring housing prices? Landsc. Urban Plan 2019, 183, 157-166. [CrossRef]

16. Council of Europe. Available online: https://rm.coe.int/CoERMPublicCommonSearchServices/DisplayDCTMContent? documentId=09000016800cce47 (accessed on 26 April 2021).

17. Official Website of Region of Istria. Spatial Program Basis of the Lim Bay and Lim Valley. 2017. Available online: https:/ /www.istraistria.hr/hr/dokumenti/prostorno-programska-osnova-limskog-zaljeva-i-limske-drage/ (accessed on 26 April 2021).

18. Hopkins, L.D. Methods for Generating Land Suitability Maps: A Comparative Evaluation. J. Am. Plan. Assoc. 1977, 43, 386-400. [CrossRef]

19. Javadian, M.; Shamskooshki, H.; Momeni, M. Application of Sustainable Urban Development in Environmental Suitability Analysis of Educational Land Use by Using Ahp and Gis in Tehran. Procedia Eng. 2011, 21, 72-80. [CrossRef]

20. Tomić, D.; Žmire, A.; Šekutor, M.; Koščak Miočić-Stošić, V.; Butula, S. Landscape Suitability Evaluation as a Tool for Development and Protection of Valuable Rural Areas. Dela Oddel. za Geogr. Filoz. Fak. v Ljubljani 2015, 44, 85-102. [CrossRef]

21. Store, R.; Kangas, J. Integrating Spatial Multi-Criteria Evaluation and Expert Knowledge for GIS-Based Habitat Suitability Modeling. Landsc. Urban Plan. 2001, 55, 79-93. [CrossRef] 
22. Eastman, J.R. Multi-criteria evaluation and GIS. In Geographical Information Systems, 2nd ed.; Goodchild, M.F., Maguire, D.J., Rhind, D.W., Eds.; Longley, John Wiley and Sons: New York, NY, USA, 1999; Volume 1, pp. 493-502.

23. Giordano, L.; Riedel, P. Multi-criteria spatial decision analysis for demarcation of greenway: A case study of the city of Rio Claro, São Paulo, Brazil. Landsc. Urban Plan. 2008, 84, 301-311. [CrossRef]

24. Phua, M.-H.; Minowa, M. A GIS-based multi-criteria decision making approach to forest conservation planning at a landscape scale: A case study in the Kinabalu Area, Sabah, Malaysia. Landsc. Urban Plan. 2005, 71, 207-222. [CrossRef]

25. Jiang, H.; Eastman, J.R. Application of fuzzy measures in multi-criteria evaluation in GIS. Int. J. Geogr. Inf. Sci. 2000, 14, 173-184. [CrossRef]

26. Greene, R.; Devillers, R.; Luther, J.E.; Eddy, B.G. GIS-Based Multiple-Criteria Decision Analysis. Geogr. Compass 2011, 5, 412-432. [CrossRef]

27. Ayalew, L.; Yamagishi, H.; Ugawa, N. Landslide susceptibility mapping using GIS-based weighted linear combination, the case in Tsugawa area of Agano River, Niigata Prefecture, Japan. Landslides 2004, 1, 73-81. [CrossRef]

28. Feizizadeh, B.; Kienberger, S. Spatially explicit sensitivity and uncertainty analysis for multicriteria-based vulnerability assessment. J. Environ. Plan. Manag. 2017, 60,1-23. [CrossRef]

29. Eastman, J.R.; Jiang, H. Fuzzy measures in multi-criteria evaluation. In Proceedings of the Second International Symposium on Spatial Accuracy Assessment in Natural Resources and Environmental Studies, Fort Collins, CO, USA, 21-23 May 1995; pp. 527-534.

30. Bioportal-Nature Protection Information System Web Portal. Available online: http:/ /www.bioportal.hr $/$ gis $/$ ?lang=en\&theme= neptune (accessed on 25 October 2020).

31. Croatian Official Gazette, NN 80/2019. Available online: https://narodne-novine.nn.hr/clanci/sluzbeni/2019_08_80_1669.html (accessed on 26 April 2021).

32. Department for Spatial Planning of the Istrian County. Spatial Plan of the Istrian County; Department for Spatial Planning of the Istrian County: Pula, Croatia, 2016; Available online: http://www.zpuiz.hr/fileadmin/dokumenti/prostorni_plan/Ostali/PPIZ_ 2016/broj14-od-29-07-2016.pdf (accessed on 26 April 2021).

33. Bale Municipality. Spatial Plan of the Bale Municipality; Bale Municipality: Bale, Croatia, 2006; Available online: https://www. opcina.bale-valle.hr/dokumenti/prostorni-planovi (accessed on 26 April 2021).

34. Kanfanar Municipality. Spatial Plan of the Kanfanar Municipality; Kanfanar Municipality: Kanfanar, Croatia, 2019; Available online: https:/ / www.kanfanar.hr/informacije-za-gradane/prostorni-plan/ (accessed on 26 April 2021).

35. Grad Rovinj-Rovigno. Spatial Plan of the City of Rovinj; Grad Rovinj-Rovigno: Rovinj, Croatia, 2019; Available online: https:/ / www.rovinj-rovigno.hr/prostorno-uredenje-gradnja-i-okolis/dokumenti-prostornog-uredenja/planovi-na-snazi/ italiano-ppug-prostorni-plan-uredenja/ (accessed on 26 April 2021).

36. Grad Rovinj-Rovigno. Master Plan of the City of Rovinj; Grad Rovinj-Rovigno: Rovinj, Croatia, 2019; Available online: https:/ / www.rovinj-rovigno.hr/prostorno-uredenje-gradnja-i-okolis/dokumenti-prostornog-uredenja/planovi-na-snazi/ gup-grada-rovinja/ (accessed on 26 April 2021).

37. Sveti Lovreč Municipality. Spatial Plan of the Sveti Lovreč Municipality; Sveti Lovreč Municipality: Sveti Lovreč, Croatia, 2017; Available online: http:/ / www.sveti-lovrec.hr/Stranica2.aspx?sid=28\&sid2=47 (accessed on 26 April 2021).

38. Svetvinčenat Municipality. Spatial Plan of the Svetvinčenat Municipality; Svetvinčenat Municipality: Svetvinčenat, Croatia, 2019; Available online: https:/ / svetvincenat.hr/prostorni-plan/ (accessed on 26 April 2021).

39. Vrsar Municipality. Spatial Plan of the Vrsar Municipality; Vrsar Municipality: Vrsar, Croatia, 2017; Available online: https:/ / www.vrsar.hr/za-gradane/prostorni-planovi/prostorni-plan-uredenja-opcine-vrsar/ (accessed on 26 April 2021).

40. Žminj Municipality. Spatial Plan of the Žminj Municipality; Žminj Municipality: Žminj, Croatia, 2017; Available online: https:/ / zminj.hr/informacije-za-gradane/prostorni-plan (accessed on 26 April 2021).

41. ENVI The Environmental Atlas-v1.7.5. Available online: http:/ / envi.azo.hr/?lang=en\&theme=clifton (accessed on 20 April 2021).

42. Istra Bike, IRTA d.o.o. Bike Trails—GPS; Istra Bike, IRTA d.o.o: Pazin, Croatia, 2019; Available online: http:/ / www.istria-bike. $\mathrm{com} /$ en/bike_trails/gps (accessed on 26 April 2021).

43. Istra Trails, IRTA d.o.o. Trails—GPS; Istra Bike, IRTA d.o.o: Pazin, Croatia, 2019; Available online: http://www.istria-trails.com/ en/trails/gps (accessed on 26 April 2021).

44. Istra Bike, IRTA d.o.o. List of Accommodation; Istra Bike, IRTA d.o.o: Pazin, Croatia, 2019; Available online: http:/ /www.istriabike.com/en/accomodation/list-of-accommodation/istra_boutique_bike_hotels (accessed on 26 April 2021).

45. Port Authority Rovinj. Available online: https://port-rovinj.giscloud.com/ (accessed on 22 April 2021).

46. Istra Bike, IRTA d.o.o. Calendar of Events; Istra Bike, IRTA d.o.o: Pazin, Croatia, 2019; Available online: http:/ / www.istria-bike. com/en/events/bike_events_calendar?\&filterRegion=\&archive=1\&search=Tra\%C5\%BEi (accessed on 24 April 2021).

47. Istra Trails, IRTA d.o.o. Calendar of Events; Istra Bike, IRTA d.o.o: Pazin, Croatia, 2019; Available online: http:/ / www.istria-trails. $\mathrm{com} /$ en/events / events_calendar? \&filterRegion=\&archive $=1 \&$ search=Tra\%C5\%BEi (accessed on 24 April 2021).

48. Lynch, K. The Image of the City, 1st ed.; The MIT Press: Cambridge, MA, USA; London, UK, 1960; pp. 72-78.

49. Realis Information Technologies. Available online: https://gis.realis.si/ (accessed on 23 April 2021).

50. Bogovac, L.; Butula, S.; Andlar, G.; Tomić Reljić, D. Approaches to landscape evaluation: Examining landscape vulnerability and sensitivity of the Island of Rab. Geoadria 2021, 26, 35-58. [CrossRef] 
51. Costa, T.; Lampert, A.D.C. Use of the Direct Method for Evaluation and Valuation of the Landscape Visual Quality. Braz. J. Aquat. Sci. Technol. 2017, 21, 1-5. [CrossRef]

52. Pires, P.d.S. Evaluation of the Visual Quality of the Landscape in the Coal Region of Criciúma-SC. Master's Thesis, Federal University of Paraná, Faculty of Forest Engineering, Agrarian Sciences Sector, Curitiba, Brasil, 1993.

53. Department for Spatial Planning of the Istrian County, Spatial Plan of the Istrian County-Land Use. Available online: https:/ / www.istra-istria.hr/media/filer_public/d9/08/d908238a-09de-4abf-80ad-98034f0d4e58/1_prostori_za_razvoj_i_ uredenje_2016s.pdf (accessed on 26 April 2021).

54. Tudor, C.A. Approach to Landscape Character Assessmet, 2nd ed.; Natural England: Worcester, UK, $2014 ;$ p. 13.

55. Croatian Motorways Ltd. Available online: https://www.hac.hr/hr/interaktivna-karta (accessed on 24 April 2021).

56. COAST Project_Inventarisation, Evaluation and Planning of Dalmatia's Coastal Landscape: River Krka Estuary. Available online: https://www.academia.edu/2508507/COAST_project_Inventarisation_Evaluation_and_Planning_of_Dalmatias_Coastal_ Landscape_River_Krka_estuary (accessed on 25 April 2021).

57. Conservation Study of the Stari Grad Plain Cultural Landscape. Available online: https: / www.bib.irb.hr/901581?rad=901581 (accessed on 26 April 2021).

58. Nature Protection Act. Available online: https://www.zakon.hr/z/403/Zakon-o-za\%C5\%A1titi-prirode (accessed on 26 April 2021 ).

59. Solecka, I. The use of landscape value assessment in spatial planning and sustainable land management-A review. Landsc. Res. 2018, 44, 1-16. [CrossRef]

60. Brown, G.; Reed, P. Validation of a Forest Values Typology for Use in National Forest Planning. Forest Sci. 2000, 46, $240-247$.

61. Department for Spatial Planning of the Istrian County. Proposal for Changes and Additions to the Territorial Plan of the Istrian County; Department for Spatial Planning of the Istrian County: Pula, Croatia, 2015; Available online: https:/ /www.istra-istria.hr/ fileadmin/dokumenti/novosti/SUO_PUO/2015/20150821_Obv_prilog_1.pdf (accessed on 26 April 2021).

62. Düzenli, T.; Özkan, D.G. Purposes of Waterscapes Usage in Landscape Architecture. In Environmental Sustainability and Water Managment, 1st ed.; Efe, R., Cürebal, I., Gad, A., Tóth, B., Eds.; St. Kliment Ohridski University Press: Sofia, Bulgaria, 2016; pp. 411-424.

63. Knez, I. Autobiographical memories for places. Memory 2006, 14, 359-377. [CrossRef] [PubMed]

64. Knez, I.; Thorsson, S. Thermal, emotional and perceptual evaluations of a park: Cross-cultural and environmental attitude comparisons. Build. Environ. 2008, 43, 1483-1490. [CrossRef]

65. Lewicka, M. Place attachment, place identity, and place memory: Restoring the forgotten city past. J. Environ. Psichol. 2008, $28,209-231$. [CrossRef]

66. Stobbelaar, D.J.; Pedroli, B. Perspectives on landscape identity: A conceptual challenge. Landsc. Res. 2011, 36, 321-339. [CrossRef]

67. Hedblom, M.; Hedenås, H.; Blicharska, M.; Adler, S.; Knez, I.; Mikusiński, G.; Svensson, J.; Sandström, S.; Sandström, P.; Wardle, D.A. Landscape perception: Linking physical monitoring data to perceived landscape properties. Landsc. Res. 2019, 45, 179-192. [CrossRef]

68. Andlar, G. Outstanding cultural landscapes of the littoral Croatia. Ph.D. Thesis, University of Zagreb, Faculty of Agriculture, Zagreb, Croatia, 2012.

69. Norton, L.R.; Inwood, H.; Crowe, A.; Baker, A. Trialling a method to quantify the 'cultural services'of the English landscape using countryside survey data. Land Use Policy 2012, 29, 449-455. [CrossRef]

70. Croatian National Tourist Board. Available online: https://www.htz.hr/sites/default/files/2020-07/HTZ\%20TUB\%20ENG_2019.pdf (accessed on 26 April 2021).

71. Buršić Matijašić, K. Not only hill forts. Histria Antiq. 2011, 20, 63-76.

72. Tomić, D.; Butula, S. Spatial Development Potential Considering Conservation Planning Criteria. Agric. Conspec. Sci. 2011, 76, 121-128.

73. Moldovan, O.T.; Kovac, L.; Halse, S. Cave Ecology, 1st ed.; Springer: Cham, Switzerland, 2018.

74. Buršić-Matijašić, K.; Žerić, H. Funeral rites and burial customs in the Bronze Age in Istria. Tabula 2013, 11, 67-92. [CrossRef]

75. Demonja, D. Istrian Romanesque Single-Naved Churches with Protruding Apses. Bibliogr. Hist. Art 1999, 23, 17-32.

76. Scheurenbrand, K.; Parsons, E.; Cappellini, B.; Patterson, A. Cycling into Headwinds: Analyzing Practices That Inhibit Sustainability. J. Public Policy Mark. 2018, 37, 227-244. [CrossRef]

77. Kilipiris, F. Sustainable Tourism Development and Local Community Involvement. Tour. Hosp. Manag. 2005, 11, 27-39.

78. Ministry of Construction and Physical Planning. Strategija Prostornog Razvoja Republike Hrvatske; Ministry of Construction and Physical Planning: Zagreb, Croatia, 2017. Available online: https:/ / mgipu.gov.hr/UserDocsImages/Zavod/Publikacije/SPRRH_e-knjiga.pdf (accessed on 21 May 2021).

79. Horwath HTL. Master Plan Turizma Istarske Županije 2015-2025; Finalni Izvještaj Master Plana; Horwath HTL: Poreč, Croatia, 2015; Available online: https:/ / www.istra.hr/hr/business-information/tzi/master-plan-turizma-istre (accessed on 19 May 2021).

80. Godine. Županijska Razvojna Strategija Istarske Županije do 2020; Godine: Pula, Croatia, 2018; Available online: https:/ /www.istraistria.hr/fileadmin/dokumenti/gospodarstvo/2018/180411_ZRS_IZ_2020.pdf (accessed on 20 May 2021).

81. Istria Bike. ICARUS BikeETrain; Istria Bike: Pazin, Croatia, 2019; Available online: http:/ /www.istria-bike.com/en/services/ ICARUS_Bike\&Train (accessed on 22 May 2021). 